\title{
16. EOCENE-OLIGOCENE SUBTROPICAL PLANKTONIC FORAMINIFERS AT SITE $841^{1}$
}

\author{
Hiroshi Nishi ${ }^{2}$ and George C.H. Chaproniere ${ }^{3}$
}

\begin{abstract}
A middle Eocene to lower Oligocene sedimentary sequence was drilled at Site 841 in the Tonga forearc region during Ocean Drilling Program Leg 135. A 56-m-thick sequence of volcanic sandstone, spanning from Cores 135-84IB-4IR to $-47 \mathrm{R}$ (549.1 to $605 \mathrm{mbsf}$ ), unconformably overlies rhyolitic volcanic basement. The middle Eocene planktonic foraminifer assemblages (P Zone ?), which occur in association with larger benthic foraminifers, include spinose species of Acarinina. Morozovella, and Truncorotaloides, but their abundance is low. Late Eocene and early Oligocene faunas are abundant and show the highest diversity of the Paleogene sequence drilled at this site. They have been assigned to Zones P15-16 and P18, respectively. The Eocene/Oligocene boundary was not recognized because of a hiatus in which Zone P17 (37.2-36.6 Ma) was missing. Another hiatus is recorded in the interval between the middle and late Eocene, spanning at least $1.8 \mathrm{Ma}$.

Paleogene assemblages of Site 841 contain equal numbers of warm- and cool-water species, an attribute of the warm middle-latitude Paleogene fauna of the Atlantic Ocean. In particular, common to high abundances of cool-water taxa, such as Globorotaloides, Catapsydrax, Tenuitella, and small globigerinids, may be related to the opening of a shallow seaway south of Tasmania permitting the influx of cool Indian Ocean waters into the South Pacific before the late Eocene (approximately $37 \mathrm{Ma}$ ),
\end{abstract}

\section{INTRODUCTION}

This paper presents the results of a study of Paleogene planktonic foraminifers recovered from Site 841 , which was drilled into the Tonga forearc region during Ocean Drilling Program(ODP) Leg 135. Site 841 is located (Fig. 1) just west of the trench slope break, approximately $55 \mathrm{~km}$ west of the axis of the Tonga Trench and $60 \mathrm{~km}$ east of the Tonga Ridge, about $140 \mathrm{~km}$ south-southwest of Site 840. The water depth at this site is $4809.8 \mathrm{~m}$, below the carbonate compensation depth (CCD).

Two holes were drilled at Site 841. Sediments recovered consist of a 605 -m-thick sequence of clay, vitric siltstone and sandstone, volcanic conglomerate and breccia, and calcareous volcanic sandstone. The sediments overlie an igneous basement composed of rhyolitic volcanic rocks. At this site, a thick middle Pleistocene to upper Miocene sequence continues down to $467.8 \mathrm{mbsf}$. This sequence is faulted against middle Miocene volcaniclastic sediments. Below $549 \mathrm{mbsf}$, lower Oligocene to middle Eocene sediments are present (Fig. 2).

\section{GENERAL LITHOSTRATIGRAPHY OF HOLE 841B}

\section{Sedimentary Sequence and Geological Age}

The sedimentary sequence penetrated at Hole 841B was divided into five lithologic units (Parson, Hawkins, Allan, et al., 1992; Fig. 2). Recovery below $72 \mathrm{mbsf}$ was poor (approximately $40 \%$ ).

Unit I ( $0-56 \mathrm{mbsf})$ consists of structureless clay interbedded with very thin- to medium-bedded vitric sand and silt turbidites and thin fallout tephra. Unit II (56-333 mbsf, $277 \mathrm{~m}$ thick) displays a thick sequence of turbidites composed of thin- to thick-bedded vitric siltstone and sandstone. Unit II is characterized by increases in the proportion of sandstone beds, bed thicknesses, and grain size downcore. This turbidite sequence overlies a 125 -m-thick sequence of poorly sorted, matrix-supported, volcanic conglomerate and breccia, interbedded with vitric siltstone and sandstone (Unit III, 333-458 mbsf).

\footnotetext{
'Hawkins, J., Parson, L., Allan, J., et al., 1994. Proc. ODP, Sci. Results, 135: College Station, TX (Ocean Drilling Program).

${ }^{2}$ Department of Earth Sciences, Faculty of Science, Yamagata University, Yamagata, 990, Japan

${ }^{3}$ Marine Geoscience Program, Bureau of Mineral Resources, P.O. Box 378, Canberra, A.C.T. 2601, Australia.
}

These sediments are interpreted as debris flows and proximal turbidites, based on their sedimentary structures. Although Unit I is dated as middle Pleistocene and Units II and III are assignable to the late Miocene, many intervals are barren of calcareous flora and fauna because of dissolution, indicating that the depth of Site 841 was at or near the CCD throughout the deposition of Units I, II, and III. In particular, the first major barren interval separates the middle Pleistocene from the upper Miocene.

Unit IV (458-549 mbsf) comprises a 91-m-thick turbidite sequence of volcanic sandstone and siltstone, possibly deposited on a submarine fan. This unit is characterized by an overall coarsening downsequence. A volcanic conglomerate near the base of the unit is interpreted as a proximal facies. Unit IV is separated from the overlying unit by a fault breccia. This unit is moderately deformed, and meso- and microscopic high-angle normal faults and fractures are common. Planktonic foraminiferal fossils are present consistently throughout this interval, yielding abundant specimens of Orbulina, Globigerinoides, Globoquadrina, and Globigerina, with minor components of Globorotalia, Sphaeroidinella, and Cassigerinella. The presence of Praeorbulina, Orbulina suturalis, Globorotalia peripheroronda, and G. archeomenardii indicates Zones N8 and N9 of Blow (1969), which are early middle Miocene in age (Chaproniere and Nishi, this volume). The preservation and abundance of specimens varies from moderate and common to poor and rare (Fig. 2), and fragmented and deformed specimens occur commonly throughout this interval,

The lowermost unit, Unit V (549-605 mbsf), is a 56-m-thick sequence of volcanic sandstone with thin interbeds of claystone. Total recovery was $18.35 \mathrm{~m}$, representing $37 \%$ of the stratigraphic section. This unit is dated as middle Eocene to early Oligocene, and the boundary between Units IV and V is thought to be an unconformity spanning approximately 13 m.y. from the early Oligocene to the early middle Miocene. These beds are faulted against a rhyolitic complex. The following four lithologies were recognized in this unit (Parson, Hawkins, Allen, et al., 1992; Fig. 3).

Lithology A (Interval 135-841B-41R-3, $113 \mathrm{~cm}$, to $-42 \mathrm{R}-1,42 \mathrm{~cm}$; 549.1-554.7 mbsf) consists of a poorly sorted, matrix-supported volcanic conglomerate that is interbedded with thin, wavy, and bioturbated volcanic sandstone beds. The conglomerate beds contain mafic rock fragments, intraformational clasts of sedimentary rocks, and silicic volcanic rocks. 


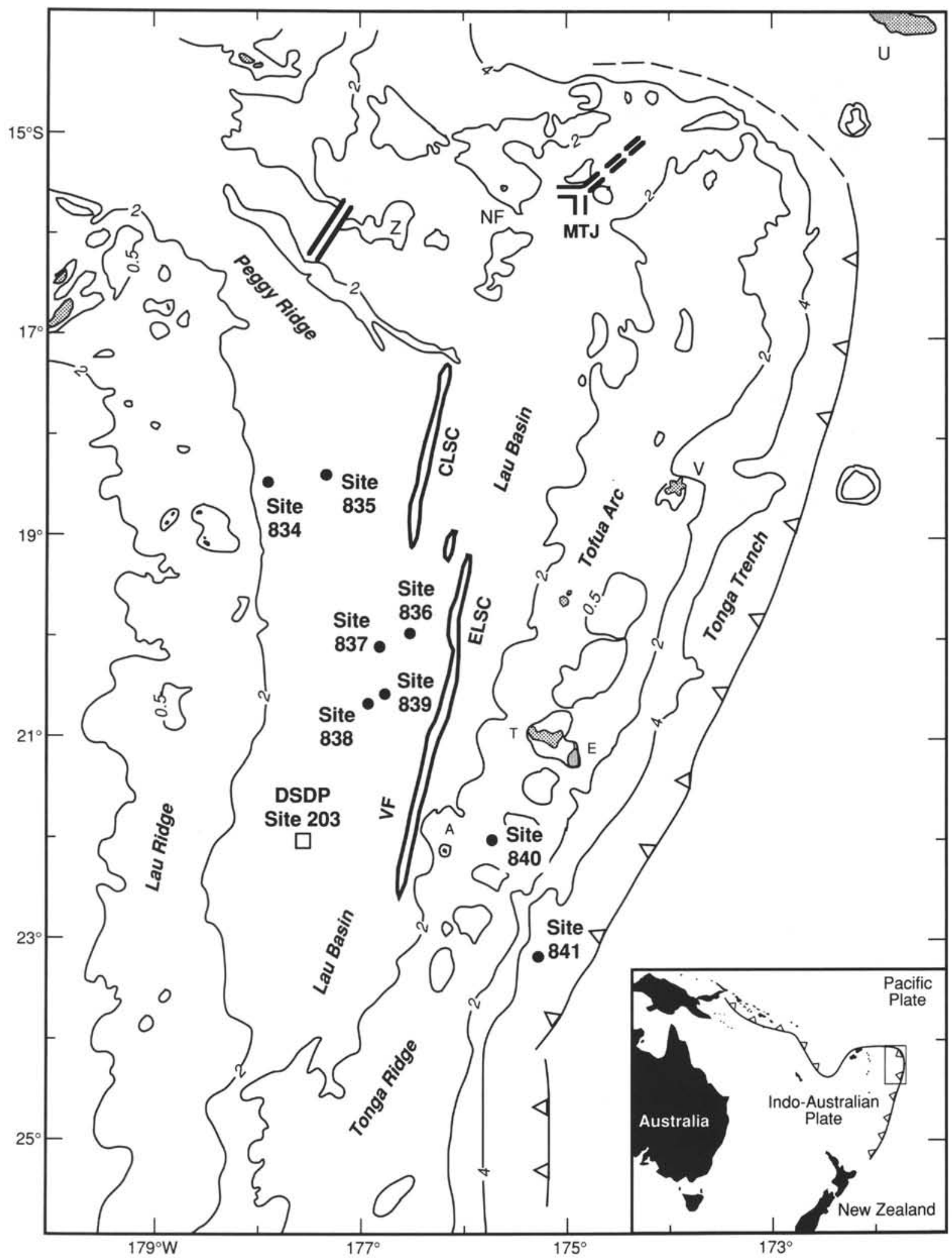

Figure 1. Regional setting for the Leg 135 drill sites showing the major geologic features of the Tonga Trench and Lau Basin system. Site 203, drilled during the Deep Sea Drilling Project (DSDP), is also shown. Z is Zephyr Shoal. Islands shown are as follows: $\mathrm{T}=\mathrm{Tongatapu}$, $\mathrm{E}=$ 'Eua, $\mathrm{V}=$ Vava'u, $\mathrm{NF}=$ Niuafo'ou, and $\mathrm{U}=$ Upolu. Locations of the Central Lau and Eastern Lau spreading centers, Valu Fa Ridge, and Mangatolu Triple Junction are shown as CLSC, ELSC, VF, and MTJ, respectively. Depths are in kilometers. 


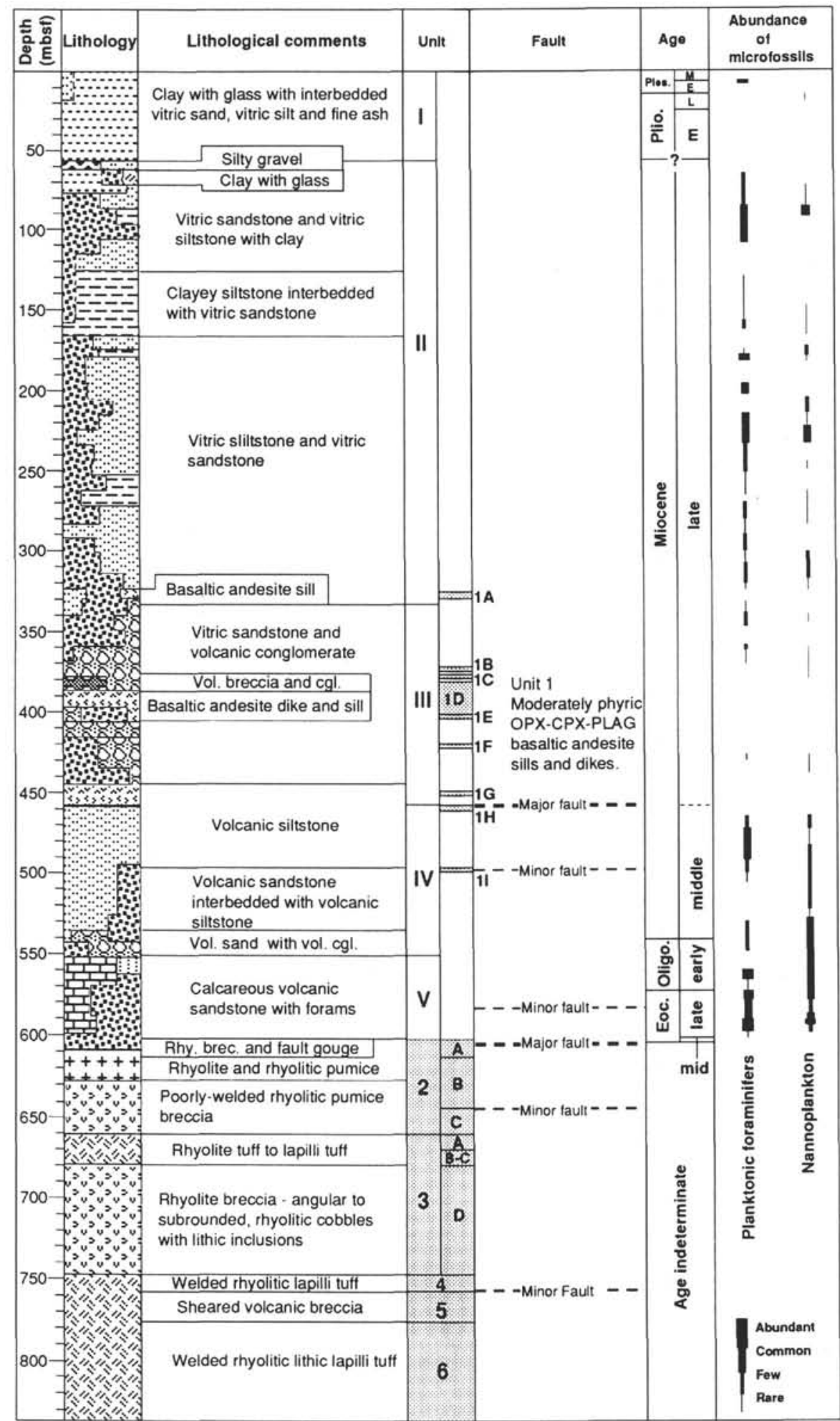

Lithologic codes:

\begin{tabular}{|c|c|c|}
\hline$\ldots$ Clay/claystone & [A] Sand/sandstone & QN Volcanic ash/tuff \\
\hline E*: Silts & C] Gravel & R: Volcanic conglomerate \\
\hline ayey silt & Calcium carbonate & Volcanic breccia \\
\hline layey s: & Acid igneous & Basic igneous \\
\hline
\end{tabular}

Figure 2. Generalized lithologic summary for Site 841 . Since this core displays low recovery, the lithologic column has been expanded vertically to make the complete column. True recovery of Site 841 was described in Parson, Hawkins, Allan, et al. (1992). 


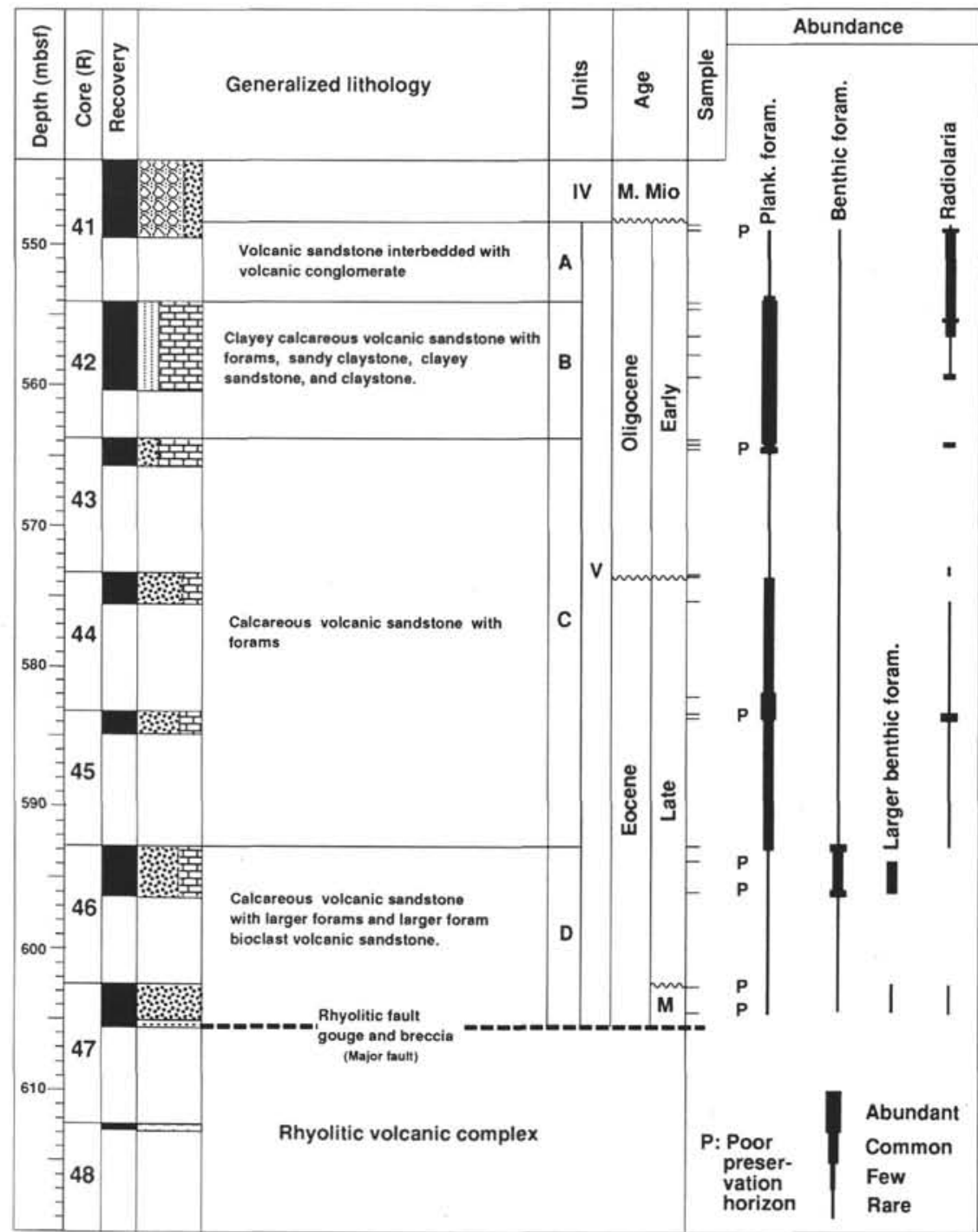

Lithology Codes:

58.8 Volcanic conglomerate

3.7. Sand/sandstone

Calcareous foraminiferal sand

Silty clay /clayey silt

mm Hiatus

Figure 3. Stratigraphic summary of the Paleogene sequence for Site 841, showing core recovery, unit boundaries, abundances of foraminifers and radiolarians, and sampling levels. Abundances are based on specimen counts of microfossils on a picking tray using disaggregated samples; this figure does not include data on larger benthic foraminifers studied in thin section.

Lithology B (Intervals 135-841B-42R-1, $42 \mathrm{~cm}$, through $-42 \mathrm{R}$ $\mathrm{CC} ; 554.7-564 \mathrm{mbsf})$ is dominant in the upper part of this unit. It is composed of clayey calcareous volcanic sandstone, sandy claystone, and claystone with foraminifers. The clayey sand beds are generally medium- to coarse-grained and are normally graded with subrounded grains of mafic rock fragments and crystals, whereas the sandy claystone and claystone are usually structureless. These beds are heavily bioturbated, and primary sedimentary structures and bedding are frequently absent.

Lithology C (Cores 135-841B-43R through -45R; 564-592.9 mbsf) consists of calcareous volcanic sandstone with foraminifers, which dominate the middle part of this unit. These sediments are bioturbated, with common Zoophycos burrows, especially in Core $135-841 \mathrm{~B}-45 \mathrm{R}$. The volcanic sandstone is usually fine grained and structureless, but thick beds ranging from 1 to $8 \mathrm{~cm}$ in thickness show normal grading. Abundant granules and pebbles up to $6 \mathrm{~mm}$ in diameter within a sandstone occur in Core 135-841B-43R.

Lithology D (Cores 135-841B-46R to -47R; 592.9-605 mbsf) is characterized by volcanic sandstone containing abundant larger benthic foraminifers together with calcareous algae.

\section{Volcanic Sequence}

Two major igneous sequences were encountered in Hole 841B. The first (Unit 1, 324.76-497.68 mbsf) is a series of thin basaltic andesite dikes or sills (0.07-8 m thick) within the upper Miocene volcanic siltstone and sandstone (Fig. 2). This sill or dike sequence is divided into nine subunits. The intrusive relationship was indicated 
by the presence of chilled margins and hyaloclastite breccias on the igneous rocks and indurated sediments at the contact.

The second major igneous sequence (Units 2 through 6) is the basement rhyolitic volcanic complex of uncertain age. No microfossils were found from the basement rock sequence, which is in fault contact with the middle Eocene shallow-water carbonates of Unit V (Figs. $2-3)$. The rhyolitic assemblage is characterized by a very high silica $\left(76 \%-80 \% \mathrm{SiO}_{2}\right)$ and very low potassium $\left(0.4 \%-1.6 \% \mathrm{~K}_{2} \mathrm{O}\right)$ content. The volcanic-rock series includes rhyolites, rhyolitic tuff, breccia, welded tuff, and lapilli tuff. It is interpreted that these rocks were formed subaerially or in a very-shallow-water environment. This complex constitutes the lower $210 \mathrm{~m}$ section of Hole 841B (Parson, Hawkins, Allen, et al., 1992).

\section{EOCENE TO OLIGOCENE BIOSTRATIGRAPHY}

\section{Methods}

The planktonic foraminifer biostratigraphy presented in this paper is based on 21 samples from Cores 135-841B-41R to -47R. Because the sediments encountered in the lower part of Hole 841B were consolidated or indurated, samples were taken from cores as a solid piece measuring approximately $1-4 \mathrm{~cm}^{2}$. One half of each rock piece was disaggregated by using a sodium sulfite $\left(\mathrm{Na}_{2} \mathrm{SO}_{4}\right)$ solution or a petroleum solvent (Varsol or naphtha). For this technique, samples are thoroughly dried and then soaked with solvent while still hot. The soaked sediments were then left, in the case of the $\mathrm{Na}_{2} \mathrm{SO}_{4}$ solution methods, for 1 or 2 weeks. After samples were broken down to small pieces, they were boiled in water containing a small quantity of sodium metaphosphate until complete disaggregation occurred. Disaggregated samples were then washed over a 250 -mesh screen $(62-\mu \mathrm{m}$ opening) with water and the residue oven dried.

At first, dried residues were scattered on a picking tray to evaluate the abundance of foraminifers and radiolarians for each sample. For estimates of species abundance, the following scale was used: $\mathrm{R}=$ rare ( $1-5$ tests on tray), $\mathrm{F}=$ few (6-10 tests on tray), $\mathrm{C}=$ common (11-25 tests on tray), and $\mathrm{A}=$ abundant (more than 25 tests on tray). The preservation state of the planktonic foraminifers is described as follows: $\mathrm{G}=$ good (little or no fragmentation), $\mathrm{M}=$ moderate (some signs of fragmentation or alteration), $\mathrm{P}=$ poor (severe fragmentation or alteration) (Fig. 3).

For analyses of planktonic foraminifers, dried samples were sieved through a 120-mesh screen (125- $\mu \mathrm{m}$ opening) and divided into coarse $(>125 \mu \mathrm{m})$ and fine $(<125 \mu \mathrm{m})$ fractions. An aliquot of $200-300$ specimens of each fraction was split with a microsplitter and used for biostratigraphic and quantitative faunal analysis. All specimens were picked from the sample aliquot in each fraction and the species were identified. In core-catcher samples and in the case when the number of specimens was fewer than 200 , the total number of specimens of both fractions was used for quantitative analyses.

\section{FORAMINIFER BIOSTRATIGRAPHY AND ZONES}

\section{Larger Benthic Foraminifers}

Reworked Eocene large benthic foraminifers are scattered throughout Unit III (Cores 135-841B-22R to -30R, lower part of upper Miocene). Cores 135-841B-46R and -47R (lithology D of Unit V) also contain larger foraminifers, including Amphistegina waiareka, Asterigerina tectoria, Asterocyclina matanzensis, Discocyclina omphala, and Operculina pacifica, as well as associated planktonic foraminifers and coralline algae and bryozoans (Chaproniere, this volume). Larger foraminifers gradually increase in number downcore from the top of Core 135-84IB-36R of Unit III to Sample 135-841B-46R-CC of Unit $\mathrm{V}$ and become rare in underlying Core 135-841B-47R. Larger foraminifers are most concentrated in Sample 135-841B-46R-CC (Fig. 3). The larger foraminifer assemblage from Cores 135-841B-46R and $-47 \mathrm{R}$ is distinctly tropical. The absence of Pellatispira places this assemblage in the East Indian Letter Stages $\mathrm{T} a_{3}$ to $\mathrm{T} b$, which is equivalent to planktonic foraminifer Zones P10 to P15 (Chaproniere, this volume; Fig. 4).

\section{Planktonic Foraminifers}

At Site 841 , the 56-m-thick Paleogene sedimentary sequence consists of $52 \mathrm{~m}$ of upper Eocene to lower Oligocene calcareous volcanic sandstone unconformably overlying $4 \mathrm{~m}$ of middle Eocene sandstones with larger foraminifers. On the basis of biostratigraphic study, Core 135-841B-47R is assigned to the middle Eocene, Cores 135-841B-46R through $-44 \mathrm{R}$ are dated as late Eocene, and Cores $135-841 \mathrm{~B}-43 \mathrm{R}$ to $-41 \mathrm{R}$ are determined to be early Oligocene (Figs. $2-3$ ). The distribution of planktonic foraminifers in Cores 135-841B$41 \mathrm{R}$ to $-47 \mathrm{R}$ is plotted in Figure 5 and Tables $1-2$.

\section{Middle Eocene (Core 135-841B-47R)}

Throughout Core 135-841B-47R, radiolarians and foraminifers are generally rare or absent. Moderately to poorly preserved specimens of planktonic foraminifers were recorded in this interval (Fig. 3). They include such species as Acarinina densa, A. spinuloinflata, Morozovella spinulosa, and Truncorotaloides topilensis, in addition to Turborotalia cerroazulensis cerroazulensis, Catapsydrax howei, Globigerinatheka mexicana mexicana, and Planorotalites renzi.

In tropical to subtropical regions, the middle Eocene faunas are characterized by spinose species of Acarinina, Morozovella, and Truncorotaloides. Although species of these genera disappear synchronously at the top of the Truncorotaloides rohri Zone and Zone P14 (e.g., Blow, 1969; Toumarkine and Luterbacher, 1985; Premoli Silva and Boersma, 1988) or diachronously within Zone P15 (Fig. 4), $M$. spinulosa and $T$. topilensis disappear at or just above Zone P14. Therefore, this faunal assemblage belongs to Zone P14 or older.

\section{Upper Eocene (Cores 135-841B-46R to -44R)}

The preservation and abundance of planktonic foraminifers in this interval vary from poor and rare (Core 135-841B-46R) to fairly good to common (Cores 135-841B-45R and -44R). Benthic foraminifers are common in samples from Core 135-841-46R and in Section $135-841 \mathrm{~B}-45 \mathrm{R}-\mathrm{CC}$, but they are rare to absent in other layers. Radiolarians are rare to absent except in Section 135-841B-45R-1 (Fig. 3).

The planktonic foraminifer faunas are characterized by species of Globigerinatheka and Hantkenina and by subspecies of Turborotalia cerroazulensis and Subbotina linaperta. Other diagnostic species in this interval are Catapsydrax africanus, Pseudohastigerina wilcoxensis, $P$. danvillensis, Chiloguembelina martini, and Planorotalites sp. The co-occurrence of $T$. cerroazulensis cocoaensis and Globigerinatheka subconglobata luterbacheri enables a correlation with Zones P15 to P16 of Blow (1969) and Berggren and Miller (1988). According to the detailed biostratigraphic and paleomagnetic studies of Nocchi et al. (1986) and Nocchi et al. (1988), the first appearance datum (FAD) of Turborotalia cerroazulensis cocoaensis occurs close to the base of Chron $\mathrm{C} 16 \mathrm{~N}$, whereas Globigerinatheka subconglobata luterbacheri disappears just above Chron C15. The upper Eocene interval at this site is, therefore, referable to Chrons C16R and C15R, which range in age from 37.2 to $39.2 \mathrm{Ma}$. The following late Eocene species disappear above Sample 135-841B-44R-1, 17-20 cm: Globigerinatheka index tropicalis, T. cerroazulensis cerroazulensis, Globigerinatheka cf. semiinvoluta, G. index index, G. subconglobata luterbacheri, and Subbotina linaperta. However, in Sample 135-841B-43R-CC, just above this level, species are rare, but include "Globigerina" pseudovenezuelana, Dentoglobigerina tripartita, and D. galavisi without late Eocene species; these are attributable to lower Oligocene Zone P18. The latest Eocene Zone P17 of Berggren and Miller (1988) that spans approximately $1 \mathrm{~m} . \mathrm{y}$. is presumably missing at this site based on the last occurrence of $G$. subconglobata luterbacheri in Section 135 $841 \mathrm{~B}-44 \mathrm{R}-1$. Another major unconformity is present between the 
Table 1. Occurrence of planktonic foraminifers in coarse $(>125 \mu \mathrm{m})$ and fine fractions $(<125 \mu \mathrm{m})$ for the Paleogene sequence in Site 841 .

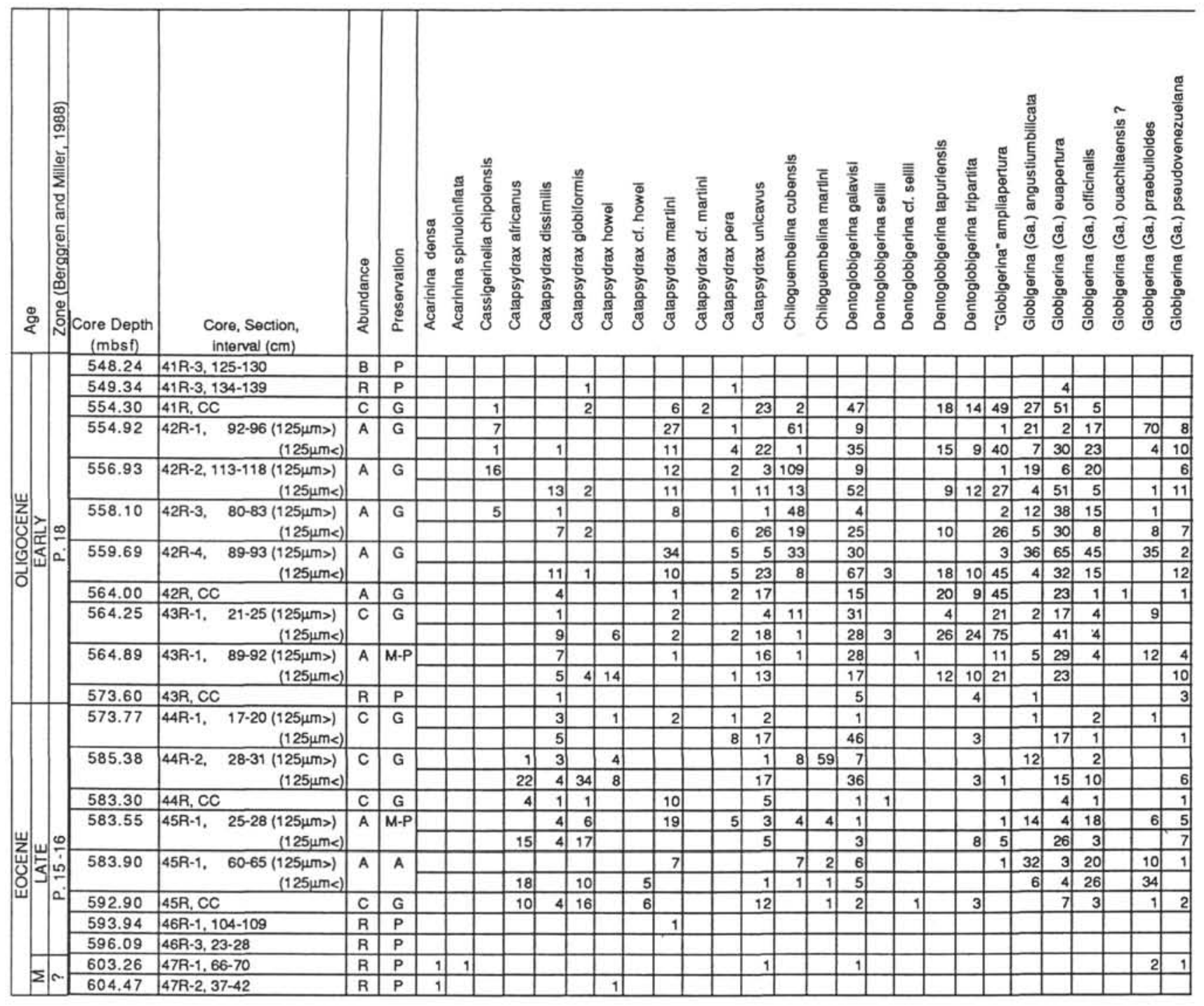

Notes: Abundance: $\mathrm{A}=$ abundant, $\mathrm{C}=$ common, and $\mathrm{R}=$ rare. Preservation: $\mathrm{G}=\operatorname{good}, \mathrm{M}=$ moderate, and $\mathrm{P}=$ poor.

middle and upper Eocene samples, spanning at least approximately 1.8 m.y. (Figs. 4-5).

\section{Lower Oligocene (Cores 135-841B-43R to -41R)}

Planktonic foraminifer faunas are rich and well preserved except in Section 135-841B-43R-CC and in the uppermost sample from Core $135-841 \mathrm{~B}-41 \mathrm{R}$, where the fauna is rare. Benthic foraminifers are rare to absent throughout the lower Oligocene interval. Radiolarians are rare to absent in the lower part, but become common upward (Fig. 3).

The planktonic foraminifer assemblages include high numbers of Pseudohastigerina, Chiloguembelina, Dentoglobigerina, Subbotina, Globigerina, and Catapsydrax. Most of the species in this interval are also present in the late Eocene. Pseudohastigerina micra, P. barbadoensis, Chiloguembelina cubensis, Dentoglobigerina tapuriensis, Tenuitella munda, and Cassigerinella chipolensis are useful biostratigraphic marker species in this interval, enabling a correlation with Zone P18, the earliest Oligocene zone of Berggren and Miller (1988) that is defined by the joint occurrence of pseudohastigerinids and chiloguembelinids. Other characteristic species are "Globigerina" ampliapertura and Turborotalia increbescens; both increase rapidly in abundance within the Oligocene sequence. Dentoglobigerina sellii has been used as a marker species for Zone P19 in Blow's (1979) zonation, but this species is rare and occurred sporadically throughout the upper Eocene to lower Oligocene interval (Fig. 4 and Table 1).

\section{QUANTITATIVE ANALYSES}

To quantify species abundances, $200-300$ specimens were counted, when possible, in both the coarse $(>125 \mu \mathrm{m})$ and fine $(<125 \mu \mathrm{m})$ fractions. Middle and upper Eocene samples from Cores 135-841B-46R and $-47 R$, and lower Oligocene Section 135-841B-43R-CC and Sample 135-841B-41R-3, 134-136 cm, were not analyzed because of specimen scarcity. Premoli Silva and Boersma (1988) assembled the large numbers of Eocene to Oligocene planktonic foraminifer species into 33 groups that reflect both evolutionary relationships and environmental significance. In this paper, we follow this grouping, and 22 Eocene to Oligocene faunal groups are described and listed in Table 3 . The quantitative distribution of these groups is shown in Figure 6 and Table 2.

\section{Upper Eocene}

The dominant groups in the coarse fraction $(>125 \mu \mathrm{m})$ of the upper Eocene sequence are Catapsydrax and Globigerinatheka. The most 
Table 1 (continued).

\begin{tabular}{|c|c|c|c|c|c|c|c|c|c|c|c|c|c|c|c|c|c|c|c|c|c|c|c|c|c|c|c|c|c|c|c|c|c|c|c|c|}
\hline 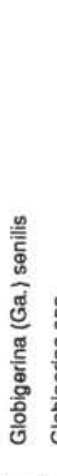 & 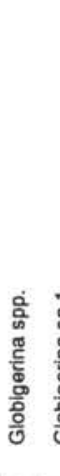 & 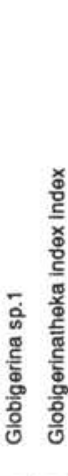 & 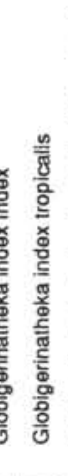 & 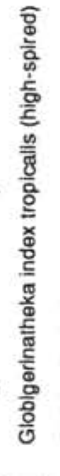 & 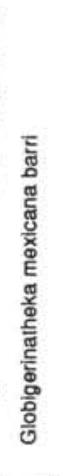 & 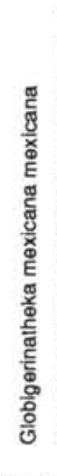 & 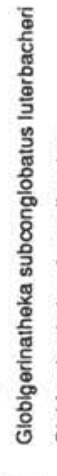 & 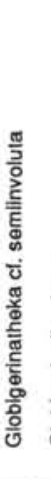 & 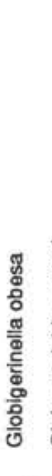 & 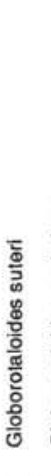 & 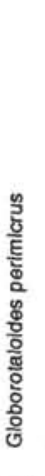 & & 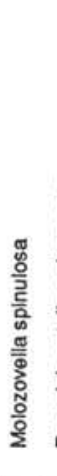 & 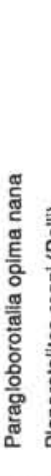 & & 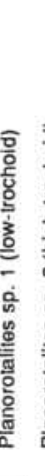 & 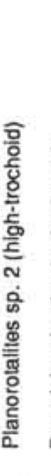 & 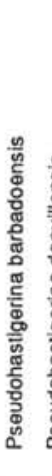 & 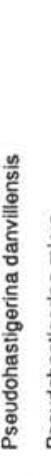 & 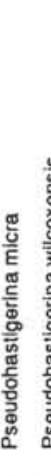 & 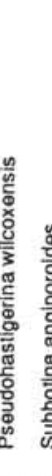 & & 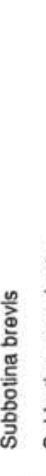 & 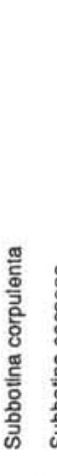 & 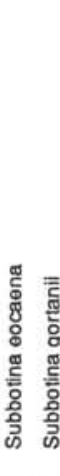 & 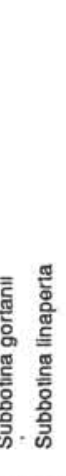 & 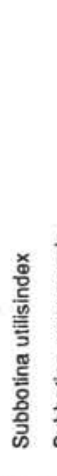 & 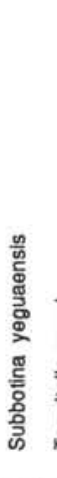 & 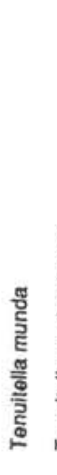 & 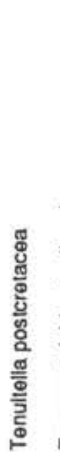 & 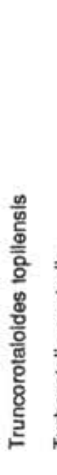 & 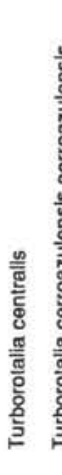 & 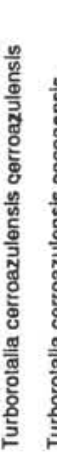 & 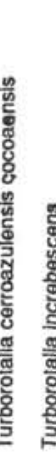 & 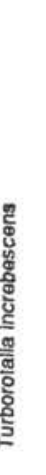 & 흥 \\
\hline & & & & & & & & & & & & & & & & & & & & & & & & & & & & & & & & & & & & $\sqrt{2}$ \\
\hline & & & & & & & & & & & & & & & & & & & & 6 & & 3 & & & & & 2 & & & & & & & & 1 & 17 \\
\hline & & & & & & & & & 5 & 27 & & & & 12 & & & & 3 & & 37 & & 13 & 1 & 3 & & 21 & & \begin{tabular}{|l|}
12 \\
\end{tabular} & & 9 & & & & & 8 & 390 \\
\hline & & & & & & & & & \begin{tabular}{l|l}
3 \\
\end{tabular} & $\begin{array}{ll}32 \\
\end{array}$ & & & & 77 & & & & & & 40 & & \begin{tabular}{|l|l|}
51 \\
\end{tabular} & & & & & & 1 & & 35 & & & & & 1 & 563 \\
\hline & & & & & & & & & 11 & \begin{tabular}{l|l}
52 \\
\end{tabular} & & & & 33 & & & & & & & & 24 & 1 & & & 5 & & \begin{tabular}{|l|}
30 \\
\end{tabular} & 1 & & & & & & 24 & 370 \\
\hline & & & & & & & & & & 142 & & & & 48 & & & & 12 & & 190 & & 69 & & & & 2 & & \begin{tabular}{|l|}
1 \\
\end{tabular} & & 104 & & & & & & 780 \\
\hline & & & & & & & & & 5 & 44 & & & & 16 & & & & 28 & & 5 & & 10 & 4 & 6 & $\begin{array}{lll}2 & 1\end{array}$ & 18 & & \begin{tabular}{|l|}
34 \\
\end{tabular} & 1 & 9 & & & & & 2 & 405 \\
\hline & & & & & & & & & 5 & 62 & & & & 13 & & & & 67 & & 22 & & 9 & & & & & & & & 5 & & & & & & 318 \\
\hline & & & & & & & & & 9 & 36 & & & & 14 & & & & & & 21 & & 14 & 6 & & & 4 & & \begin{tabular}{|l|}
11 \\
\end{tabular} & 14 & 1 & & & & & & 309 \\
\hline & & & & & & & & & $14 \sqrt{2}$ & 206 & & & & 17 & & & & 79 & & 73 & & 14 & & & & & & 2 & & 21 & & & & & & 719 \\
\hline & & & & & & & & & 4 & 55 & & & & 30 & & & & & & 18 & & 19 & 2 & 2 & 5 & 7 & & \begin{tabular}{|l|}
20 \\
\end{tabular} & 5 & 3 & & & & & & 434 \\
\hline & & & & & & & & & & 5 & & & & 2 & & & & 2 & & 1 & & 6 & & 5 & & 8 & 1 & & 7 & & & & & & 2 & 169 \\
\hline & 3 & & & & & & & & & 46 & & & & 8 & & & & & & 57 & & 5 & & & & & & & 3 & 3 & & & & & 4 & 231 \\
\hline & & & & & & & & & & 3 & & & & & & & & 2 & & 1 & & 6 & & 3 & & 4 & 2 & 4 & 1 & & & & & & 17 & 265 \\
\hline & 2 & & & & & & & & 4 & 21 & & & & 10 & & & & & & 59 & & 22 & 3 & & & & & & & 6 & & & & & 7 & 246 \\
\hline & & & & & & & & & & & & & & & & & & & & & & 10 & & 2 & & 3 & & 1 & & & & & & & $\sqrt{6}$ & 146 \\
\hline & & & & & & & & & & 1 & & & & & & & & & & & & 7 & & & 1 & & 1 & & & & & & & & & 17 \\
\hline & & & & & & & & 1 & & 1 & & & & & & & & & & 56 & & 2 & & & & 3 & & & & & & & 1 & & & 77 \\
\hline & & 45 & 5 & & & 1 & 12 & 4 & & & & & & & & & & & & & & 4 & 1 & 6 & & \begin{tabular}{|l|l}
6 & 4 \\
\end{tabular} & & \begin{tabular}{|l|}
41 \\
\end{tabular} & & & & & 11 & & & 218 \\
\hline & 1 & & \begin{tabular}{l|l|}
2 & 10 \\
\end{tabular} & & & 5 & & 6 & & 6 & 1 & & & 3 & & 37 & 9 & & & 204 & 7 & 1 & & + & & 1 & & 1 & & 10 & & & 8 & & & 400 \\
\hline & & & \begin{tabular}{|l|l|}
3 & 77 \\
\end{tabular} & & 6 & \begin{tabular}{|l|}
12 \\
\end{tabular} & & 13 & & & & 3 & & & & & & & & & & 13 & 7 & 11 & & \begin{tabular}{l|l|}
5 & 10 \\
\end{tabular} & & \begin{tabular}{|l|}
49 \\
\end{tabular} & & & & & 45 & & & 365 \\
\hline & 1 & & 11 & & & 4 & & 3 & & & & & & 1 & & & & & & 13 & & 5 & & 7 & 1 & 9 & & & & & & 21 & 14 & & & 84 \\
\hline & & & 9 & & 1 & 5 & & 2 & 1 & 38 & & & & 3 & & 4 & 10 & & & 58 & & 12 & & - & & 5 & & 8 & & 2 & & & & & & 252 \\
\hline & & & 40 & 5 & & 9 & & 20 & & 4 & & & & & & & & & & 6 & & 10 & & \begin{tabular}{l|l}
7 & 1 \\
\end{tabular} & 14 & \begin{tabular}{l|l}
4 & 7
\end{tabular} & & 3 & & 1 & & 5 & 4 & & & 223 \\
\hline & & & & & & & & & & \begin{tabular}{l|l}
13 \\
\end{tabular} & & & & 2 & & 17 & 3 & 6 & & 56 & & 1 & & & & 4 & & & & \begin{tabular}{|c|}
11 \\
\end{tabular} & & & 2 & & 1 & 198 \\
\hline 2 & & 1 & 47 & & & 6 & & 5 & & 20 & & 6 & & 3 & & & 2 & & & 28 & & 19 & & 5 & 8 & 26 & & 1 & & & & 2 & 2 & & & 290 \\
\hline & 1 & & 26 & 6 & & \begin{tabular}{|l|l|}
15 \\
\end{tabular} & & 16 & & 3 & & & & & & & & & & 12 & & 4 & & 7 & & $\begin{array}{ll}220 \\
\end{array}$ & & 5 & & & & \begin{tabular}{l|l}
3 & 2 \\
\end{tabular} & 29 & 3 & & 186 \\
\hline & & & & & & & & & & & & & & & & & & & & & & & & & & \begin{tabular}{l|l}
1 & 2 \\
\end{tabular} & & 1 & & & & & 1 & & & 5 \\
\hline & & & & & & 1 & & & & & & & & & & & & & & & & & & & & & & & & & & & 1 & & & 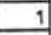 \\
\hline & & & & & & & & & & & & & 2 & & & & & & & & & & & & & & & & & & 1 & & & & & 10 \\
\hline & & & & & & & & & & & & & & & & & & & & & & & & & & & & & & & & & & & & \\
\hline
\end{tabular}

abundant species is Globigerinatheka index tropicalis. It exceeds $10 \%$ of the assemblage and attains a maximum abundance of $17 \%$. The various subspecies of Turborotalia cerroazulensis also occur in fairly high abundance $(>10 \%)$ in some samples. Among the subspecies, $T$. cerroazulensis cerroazulensis is the most common, and its highest abundance (28\%) is recorded in Sample 135-841B-44R-2, $28-31 \mathrm{~cm}$. High-spired subbotinids (Subbotina corpulenta and $S$. gortanii) and the Dentoglobigerina tripartita group (D. tripartita, D. tapuriensis, and D. sellii) occur consistently throughout the upper Eocene, but their abundances are less than $7 \%$ (generally $1 \%-3 \%$ ). Low-spired subbotinids (Subbotina eocaena and S. yeguaensis), large globigerinid groups ("Globigerina" euapertura and "Globigerina" pseudovenezuelana), and Dentoglobigerina (D. galavisi) increase in the uppermost part of Core 135-841B-44R-1 where $S$. yeguaensis and D. galavisi attain a peak abundance of approximately $20 \%$. Hantkenina is rare and scattered throughout the sequence.

The fine fractions $(<125 \mu \mathrm{m})$ are dominated by Pseudohastigerina, often reaching more than $20 \%$ with a maximum of $72 \%$ in the uppermost Eocene Sample 135-841B-44R-1, 17-20 cm. Other dominant components include Catapsydrax, Globigerina, Globorotaloides, and Chiloguembelina, but these are generally less than $20 \%$. The populations of such dominant groups as Globigerinatheka and T. cerroazulensis in coarse fractions are rare $(<4 \%)$ in the fine fractions.

\section{Lower Oligocene}

Planktonic foraminifer faunas in the coarse fractions $(>125 \mu \mathrm{m})$ are dominated by large globigerinid groups, along with less common Catapsydrax, Dentoglobigerina, "Globigerina" ampliapertura group, and Globorotaloides (Fig. 6). The following species increase in abundance downsection through the Oligocene sequence: "G." ampliapertura, Turborotalia increbescens, Dentoglobigerina galavisi, "Globigerina" euapertura, Subbotina angiporoides, Dentoglobigerina tripartita groups, and Globorotaloides suteri.

One of the characteristic features in this interval is a high abundance of "G." ampliapertura groups ("Globigerina" ampliapertura and Turborotalia increbescens). "G." ampliapertura attains approximately $30 \%$ in the lower part, whereas T. increbescens first occurs in the Oligocene sequence and does not exceed $10 \%$ (Fig. 6). The Dentoglobigerina tripartita group displays an abundance peak at the same levels, but this species is generally less than $10 \%$. "G." euapertura and D. galavisi are consistently present and fluctuate in abundance from $7 \%$ to $15 \%$. Catapsydrax decreases slightly upward; $C$. unicavus is most common $(<9 \%)$, and others do not exceed $5 \%$.

The fine fractions $(<125 \mu \mathrm{m})$ are dominated by Pseudohastigerina micra and G. suteri. Their abundances fluctuate from $6 \%$ to $29 \%$ but attain approximately $20 \%$ in many samples. Although Cassigerinella 


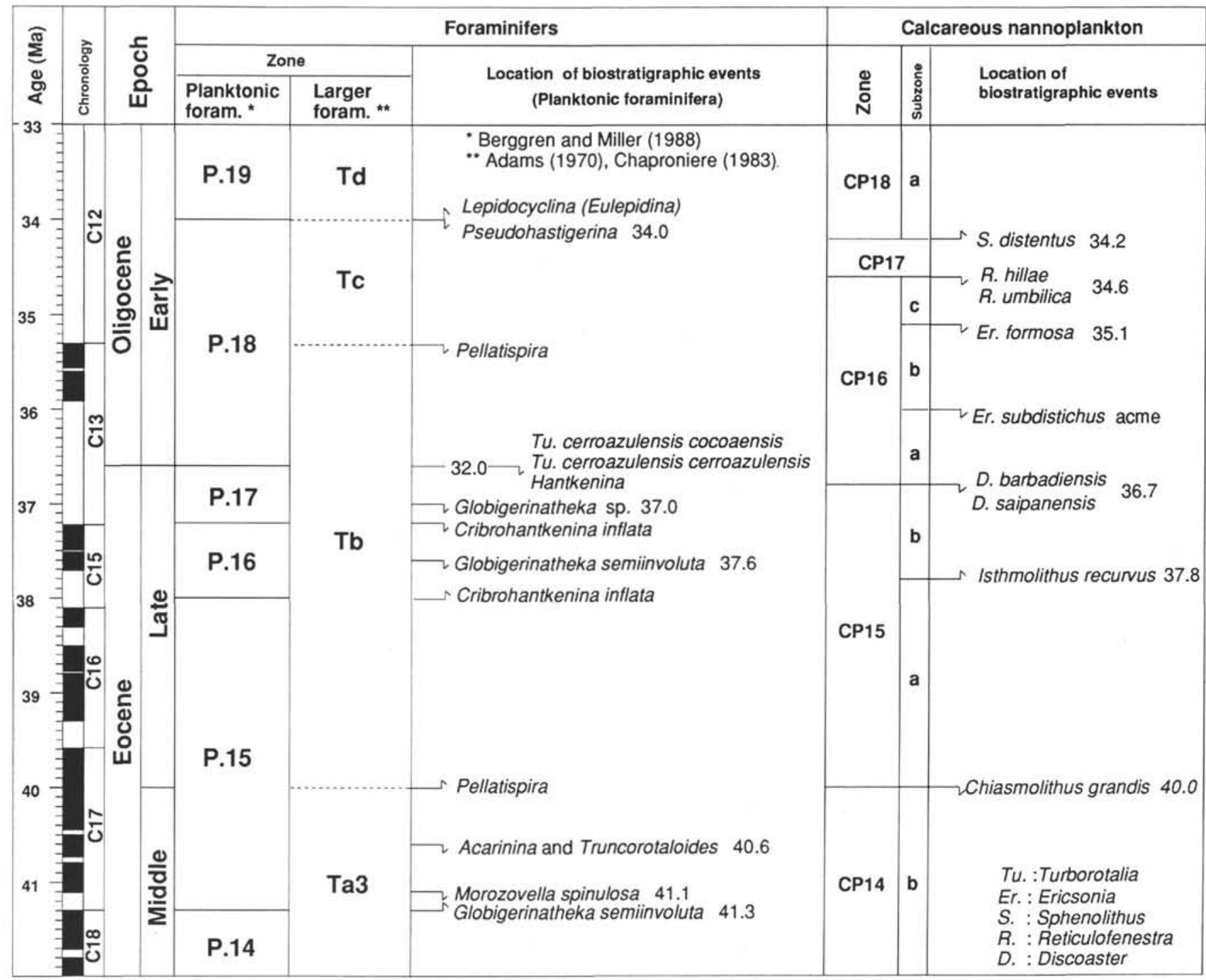

Figure 4. Biostratigraphic standard for the Paleogene sequence of Leg 135. Age (in Ma) and magnetostratigraphic scale are adopted from Berggren et al. (1985) and Aubry et al. (1988), planktonic foraminifer zones from Berggren and Miller (1988), larger foraminifer zones from Adams (1970, 1984) and Chaproniere (1981, 1983), and nannoplankton zones from Okada and Bukry (1980).

chipolensis is a useful marker species in the earliest Oligocene, its occurrence is rare $(1 \%-2 \%)$ and sporadic. Chiloguembelina cubensis increases upward through the Oligocene sequence and exceeds $10 \%$ in the upper part. Tenuitella and Paragloborotalia nana also display the same trend and exceed 5\% in the upper part of Core 135-841B$42 \mathrm{R}$. Except for the D. tripartita group and the low-spired subbotinids, the dominant species in the coarse fractions are present in reduced numbers in the fine fractions.

\section{DISCUSSION}

\section{Bioprovince Indexes of the Paleogene Ocean}

In the Southwest Pacific today, there are a number of surface-water masses bounded by oceanographic fronts that are marked by distinctive planktonic faunas and floras. They are arranged with a distinct latitudinal zonality (Kennett and von der Borch, 1986). This floral and faunal latitudinal differentiation (provincialism) existed throughout the Cenozoic, the composition changing with time (e.g., Haq et al., 1977; Premoli Silva and Boersma, 1988). These changes have involved both major latitudinal shifts of assemblages and major evolutionary change between old and new dominant groups, altering the make-up of the assemblages. In particular, the latitudinal migration of warm- and cool-water taxa has been interpreted as being caused by major climatic fluctuations and controlled mainly by a changing latitudinal thermal gradient (Haq et al., 1977; Murphy and Kennett, 1986). Shifts of low-latitude (warm) assemblages toward high latitudes reflect warming periods, whereas invasions of high-latitude (cool) assemblages toward low latitudes indicate cooling.

In Paleogene time the bioprovincialism and migration of the faunas have been recognized by a series of bioprovincial studies in the Atlantic province (Boersma and Premoli Silva, 1986; Premoli Silva and Boersma, 1988, 1989; Spezzaferri and Premoli Silva, 1991). During the early late Eocene, for example, lower latitude faunas were dominated by such taxa as Globigerinatheka, Subbotina, Pseudohastigerina, and subspecies of the Turborotalia cerroazulensis lineage, all previously typical of middle latitudes and of gyre margins (Boersma and Premoli Silva, 1986; Premoli Silva and Boersma, 1988). These bioprovincial studies have also revealed the existence 


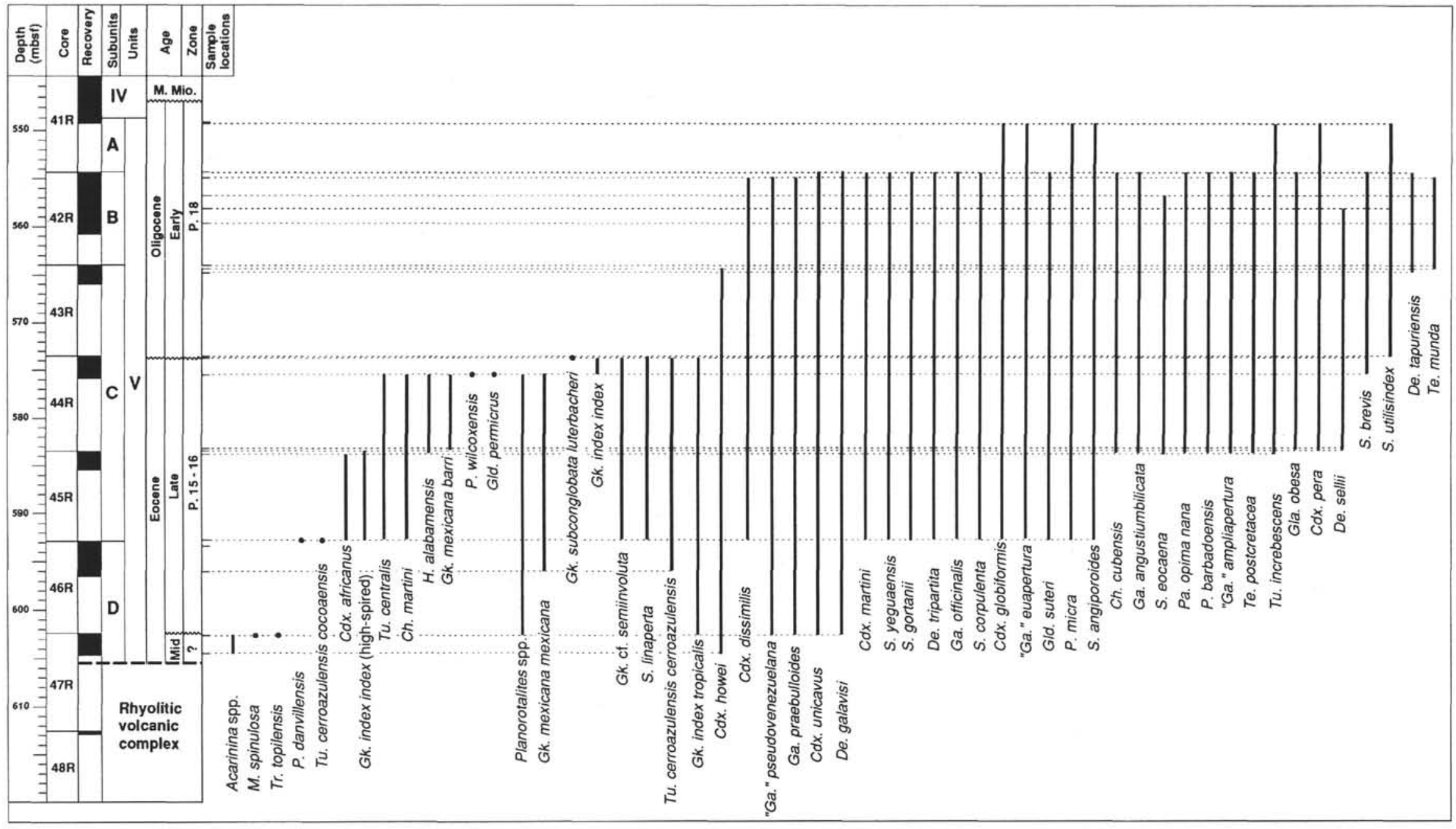

Figure 5. Stratigraphic distribution of planktonic foraminifers throughout the Paleogene sequence at Site 84l. Cdx. $=$ Catapsydrax, Ch. $=$ Chiloguembelina, De. $=$ Dentoglobigerina, Ga.$=$ Globigerina, Gk. $=$

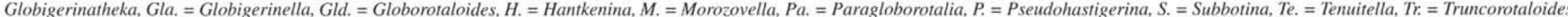
and Tu. $=$ Turborotalia . 
Table 2. Percentage of planktonic foraminifers in coarse $(>125 \mu \mathrm{m})$ and fine fractions $(<125 \mu \mathrm{m})$ for the Paleogene sequence in Site 841 .

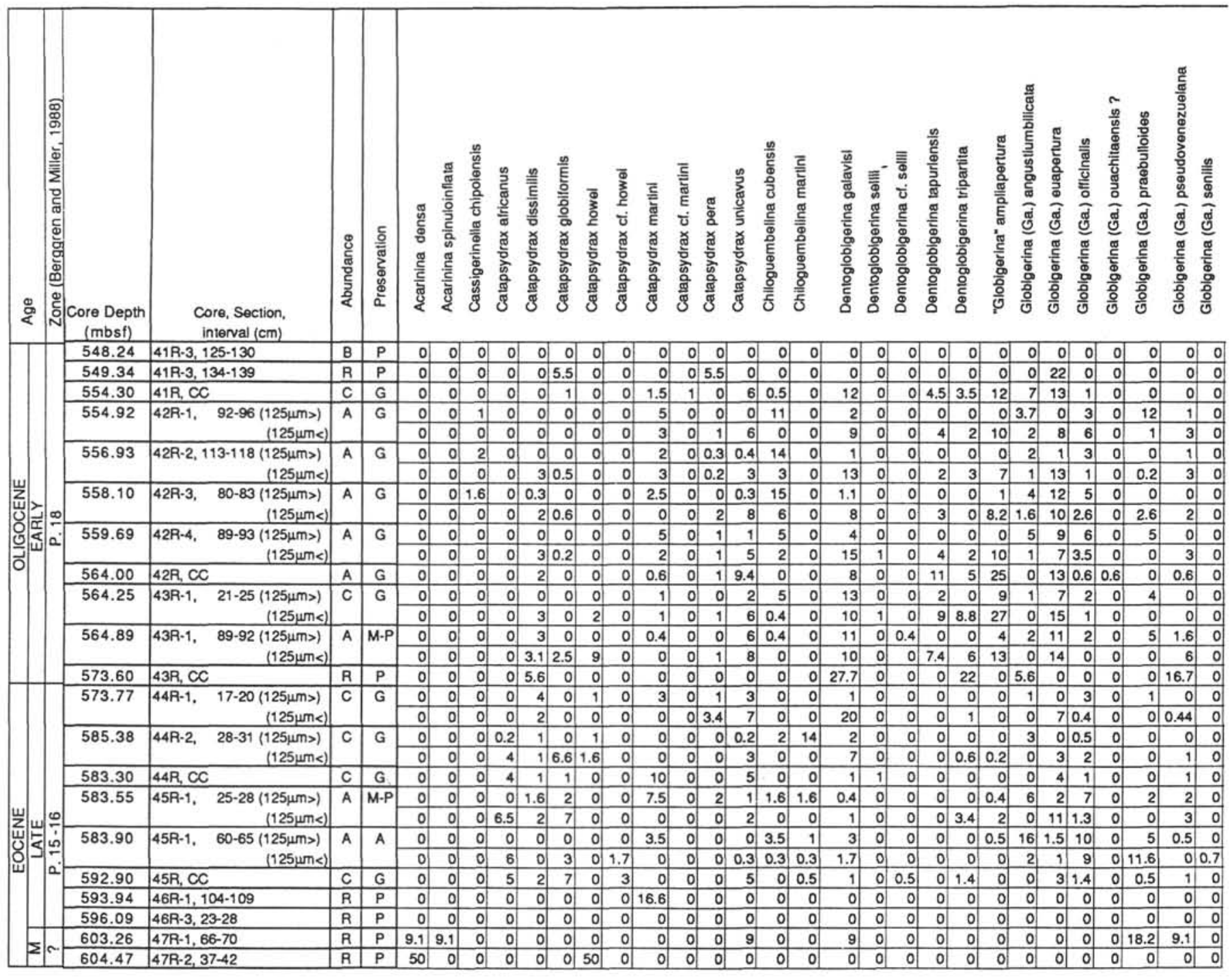

Note: See Table 1 for explanation of the symbols used.

of three latitudinal bioprovincial groups of planktonic foraminifers during the late Eocene to early Oligocene interval. The characteristics of these groups are summarized as follows:

1. In the latest Eocene to earliest Oligocene, Globoaradrina $(=$ Dentoglobigerina in this paper) and Turborotalia are the low-latitude (warm-water) index forms. The early Oligocene faunas were relatively homogeneous throughout different latitudes, but lower latitude faunas contained the highest abundance of Turborotalia, particularly Turborotalia increbescens. This group became more abundant close to the Eocene/Oligocene boundary and continued into the early Oligocene. True Globoquadrina tripartita $(=$ Dentoglobigerina tripartita) was also typical of low latitudes; it was never common outside the subtropics.

2. Diagnostic features of the middle latitude bioprovince are (a) the survival of Globigerinatheka index index and $G$. index tropicalis upward to the Eocene/Oligocene boundary (e.g., Keller, 1983; Jenkins and Srinivasan, 1985; Premoli Silva and Boersma, 1988), (b) the occurrence of middle latitude forms of Globigerinatheka semiinvoluta (with smaller supplementary apertures) more abundantly than in low latitudes, and (c) common to high abundances of large-globigerinidform species, including "Globigerina" euapertura and Subbotina linaperta, which are important components of the middle-latitude assemblages. By the late Eocene, however, $S$. linaperta became more typical of middle to lower latitudes.

3. High-latitude assemblages consist largely of high-spired subbotinids, Catapsydrax, Globorotaloides, Tenuitella, and small globigerinids. Such higher latitude index forms as Catapsydrax and Globorotaloides nevertheless occur at all latitudes.

\section{Eocene to Oligocene Bioprovince for Site 841}

The present position of Site 841 is within the subtropical biogeographic province, and is slightly influenced by the eastward-flowing Tasman Current. This site is thought to have been located at about $30^{\circ}$ to $40^{\circ} \mathrm{S}$ in the late Eocene to early Oligocene (Fig. 7) before the opening and growth of a number of marginal seas such as the South Fiji Basin, Loyalty Basin, and Norfolk Basin. These marginal seas were formed during the Eocene to Oligocene and expanded eastward (Packham and Andrews, 1975; Weissel et al., 1982; Davey, 1982; Edwards, 1975; Kroenke, 1984).

During the middle to late Eocene, the presence of tropical IndoPacific faunas typified by such larger benthic foraminifers as Amphistegina, Asterocyclina, Discocyclina, Operculina, Heterostegina, Spiroclypeus, Sherbornina, and Gypsina? discus indicates that Site 841 belonged to a tropical/subtropical bioprovince (Chaproniere, this 


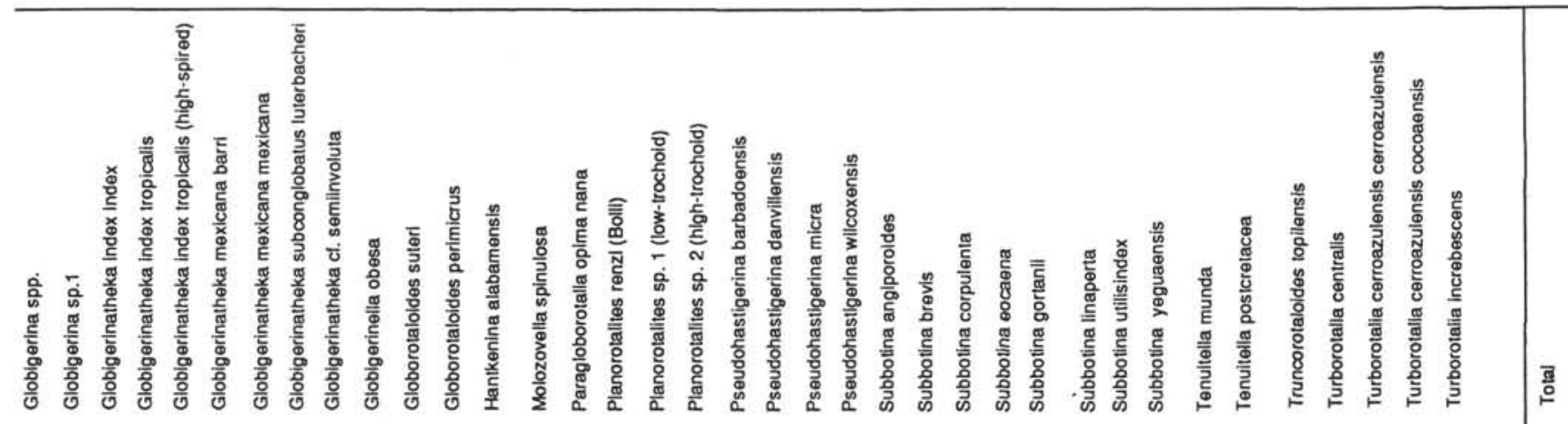

\begin{tabular}{|c|c|c|c|c|c|c|c|c|c|c|c|c|c|c|c|c|c|c|c|c|c|c|c|c|c|c|c|c|c|c|c|c|c|c|c|c|c|}
\hline 0 & 0 & 의 & 0 & 0 & 0 & 0 & of & 0 & 0 & 0 & 0 & of & 0 & 0 & 0 & 0 & 0 & 0 & 0 & 0 & 0 & 0 & & 0 & 0 & 0 & 0 & 0 & 0 & 0 & 0 & 0 & 0 & 0 & 0 & 0 & 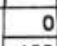 \\
\hline 0 & 0 & 0 & 0 & 0 & 0 & 0 & 0 & 0 & 1 & 7 & 0 & 0 & 0 & 3 & 0 & 0 & 0 & 1 & 0 & at & 0 & 3 & 0 & 1 & 0 & 5 & 0 & 0 & 3 & 0 & 2 & 0 & 0 & 0 & 0 & 2 & 100 \\
\hline 0 & 0 & 0 & 0 & 0 & 0 & 0 & 0 & 0 & 0.5 & 6 & 0 & 0 & 0 & 14 & 0 & 0 & 0 & 0 & 0 & 25 & 0 & 9 & 0 & 0 & 0 & 0 & 0 & 0 & 0 & 0 & 8 & 0 & 0 & 0 & 0 & 0 & 100 \\
\hline 0 & 0 & 0 & 0 & 0 & 0 & 0 & 0 & 0 & 3 & 13 & 0 & 0 & 0 & 8 & 0 & 0 & 0 & 0 & 0 & 0 & 0 & 6 & 0 & 0 & 0 & 1 & 0 & 0 & 8 & 0 & 0 & 0 & 0 & 0 & 0 & 6 & 100 \\
\hline 0 & 0 & 0 & 0 & 0 & 0 & 0 & 0 & 0 & 1 & 11 & 0 & 0 & 0 & 4 & 0 & 0 & 0 & 7 & 0 & 1 & 022 & 2.5 & \begin{tabular}{l|l}
11 \\
\end{tabular} & 1.5 & 0 & 4.4 & 0 & 0 & 8 & \begin{tabular}{l|}
0.2 \\
\end{tabular} & 2 & 0 & 0 & 0 & o. & 0.5 & 100 \\
\hline 0 & 0 & & 0 & 0 & 0 & 0 & 0 & 0 & 1.6 & 19 & 0 & 0 & 0 & 4 & 0 & 0 & 0 & 21 & 0 & 7 & 0 & 3 & 0 & 0 & 0 & 0 & 0 & 0 & 0 & 0 & 1.6 & 0 & 0 & 이 & 0 & 0 & 100 \\
\hline 0 & 0 & 0 & 0 & 0 & 0 & 0 & 0 & 0 & 3 & 12 & 0 & 0 & 0 & 4.5 & 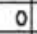 & 0 & 0 & 0 & 0 & 7 & 0 & 5 & 2 & 0 & 0 & 1 & 0 & 0. & 3.6 & 5 & 0.3 & 0 & 0 & 0 & 0 & 0 & 100 \\
\hline 0 & 0 & 0 & 0 & 0 & 0 & 0 & 0 & 0 & 2 & 29 & 0 & 0 & 0 & 2 & 0 & 0 & 0 & 11 & 0 & 10 & 0 & 2 & 0 & 0 & 0 & 0 & 0 & 0 & 0 & 0 & 3 & 0 & 0 & 0 & of & 0 & 100 \\
\hline 1 & 0 & 0 & 0 & 0 & 0 & 0 & 0 & 0 & 0 & 20 & 0 & 0 & 0 & 3 & 0 & 0 & 0 & 0 & 0 & 24 & 0 & 2 & 0 & 0 & 0 & 0 & 0 & 0 & 0 & 1 & 1 & 0 & 0 & 0 & 0 & 2 & 100 \\
\hline 0 & 0 & & 0 & 0 & 0 & 0 & 0 & 0 & 0 & 1 & 0 & 0 & 0 & 0 & 0 & 0 & 0 & 1 & & 0.4 & 0 & 2 & 0 & 1 & 0 & 1 & 0 & 1 & 1 & 0.4 & 0 & 0 & 0 & 0 & 0 & 6 & 100 \\
\hline 1 & 0 & & 0 & 0 & 0 & 0 & 0 & 0 & 1.6 & 8 & 0 & 0 & 0 & 4 & 4 & 0 & 0 & 0 & 0 & 23 & 0 & $\begin{array}{lll}9 & 1 .\end{array}$ & 1.2 & 0 & 0 & 0 & 0 & 0 & 0 & 0 & 2.4 & 0 & 0 & 0 & 0 & 3 & 100 \\
\hline 0 & 0 & & 0 & 0 & 0 & 0 & 0 & 0 & 0 & 0 & 0 & 0 & 0 & 0 & 0 & 0 & 0 & 0 & 0 & 0 & 0 & 6 & 0 & 1 & 0 & 2 & 0 & 0 & 1 & 0 & 0 & 0 & 0 & 0 & 0 & 10 & 100 \\
\hline 0 & 0 & & 0 & 0 & 0 & 0 & 0 & 0 & 0 & 5.6 & 0 & 0 & 0 & 0 & 0 & 0 & 0 & 0 & 0 & 0 & 0 & 0 & 0 & & 5.6 & 0 & $\begin{array}{l}05 \\
\end{array}$ & 5.6 & 0 & 0 & 0 & 0 & 0 & 0 & 0 & 5.6 & 100 \\
\hline 0 & 0 & 0 & 0 & 0 & 0 & 0 & 0 & 1 & 0 & 1 & 0 & 0 & 0 & 0 & 0 & 0 & 20 & 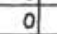 & 0 & 72 & 0 & 3 & 0 & 0 & 0 & 0 & 4 & 0 & 0 & 0 & 0 & 0 & 0 & 1 & 0 & 0 & 100 \\
\hline 0 & 0 & 20 & 0 & 0 & 0 & 0.4 & 5 & 2 & 0 & 0 & 0 & 0 & 0 & 0 & 0 & 0 & 0 & 0 & 0 & 0 & 0 & & 0.4 & 3 & 0 & 3 & 4 & 0 & 18 & 0 & 0 & & 0 & 5 & 0 & 0 & 100 \\
\hline 0 & 0 & 0 & 0 & 0 & 0 & 0 & 0 & 0 & 0 & 6.5 & 0 & 0 & 0 & 1 & 0 & 8 & 1.5 & 3 & 0 & 28 & & 0.5 & 0 & 0 & 0 & 0 & 0 & 0 & 0 & 0 & 5.5 & 0 & 0 & 1 & & 0.5 & 100 \\
\hline 0 & 0 & 0 & 16 & 0 & 0 & $\sqrt{0}$ & 0 & 1.7 & 0 & 7 & 0 & 2 & 0 & 1 & 0 & 0 & 0.7 & 0 & 0 & 10 & 0 & 6 & 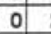 & 2 & 3 & 7 & 9 & 00 & 0.3 & 0 & 0 & 00 & 0.7 & 0.7 & 0 & 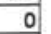 & 100 \\
\hline \begin{tabular}{l|l}
0.5 \\
\end{tabular} & 0 & 0 & 12 & 2.7 & 0 & 6.8 & 0 & 7 & 0 & 1.4 & 0 & 0 & 0 & 0 & 0 & 0 & - & 00 & 0.5 & 5 & 0 & 2 & 0 & 3 & 0 & 1 & 9 & 0 & 2 & 0 & 0 & \begin{tabular}{l|l}
0 & 1 \\
\end{tabular} & 1.4 & 13 & 1.4 & & 100 \\
\hline 0 & 0 & 0 & 0 & 0 & 0 & 0 & 0 & 0 & 0 & 0 & 0 & 0 & 0 & 0 & 0 & 0 & 0 & 0 & 0 & 0 & 0 & 0 & 0 & 0 & & 6.73 & 33 & 016 & 16.7 & 0 & 0 & 0 & 0 & 17 & 0 & 0 & 100 \\
\hline 0 & 0 & 0 & 0 & 0 & 0 & 50 & 0 & 0 & 0 & 0 & 0 & 0 & 0 & 0 & 0 & 0 & 0 & 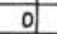 & 0 & 0 & 0 & 0 & 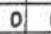 & 0 & 0 & 0 & 0 & 0 & 0 & 0 & 0 & 0 & 0 & 50 & 0 & 0 & 100 \\
\hline 0 & 0 & 0 & 9.1 & 0 & 0 & 0 & 0 & 0 & 0 & 0 & 0 & 0 & 18.2 & 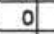 & 0 & 0 & 0 & 0 & 0 & 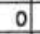 & 0 & 0 & 8 & 0 & 0 & 0 & 0 & 0 & 0 & 0 & 0 & 9.1 & 0 & 0 & 0 & & 100 \\
\hline 이 & 0 & 0 & & 0 & & 0 & 0 & 0 & 0 & 0 & 0 & 0 & 0 & 0 & & & 0 & 0 & & & 0 & \begin{tabular}{l|l}
0 \\
\end{tabular} & & & 0 & & 0 & & 0 & 0 & 0 & 0 & 0 & & 0 & 0 & 100 \\
\hline
\end{tabular}

volume). During the late Eocene, however, planktonic foraminifer assemblages at this site include high abundances $(>10 \%)$ of cool-water taxa, such as Catapsydrax, Globorotaloides, and Globigerina (Gradstein and Srinivastava, 1980) at some horizons. Other faunal characteristics of the latest Eocene include (1) faunas characterized by high abundances of Globigerinatheka index tropicalis, Turborotalia cerroazulensis cerroazulensis, and Pseudohastigerina micra; and (2) G. semiinvoluta, which was recovered at Hole $841 \mathrm{~B}$, does not exhibit well-developed supplementary apertures and is always smaller in size than the typical form. These nontypical forms are identified in this paper as Globigerinatheka cf. semiinvoluta.

In the Oligocene sequence in Hole $841 \mathrm{~B}$, the planktonic foraminifer assemblages are characterized by fairly high abundances of "Globigerina" ampliapertura in the lowermost part of the Oligocene sequence, whereas $T$. increbescens is less abundant. Typical warmwater indicators in the Atlantic Ocean such as Globoquadrina tripartita (= Dentoglobigerina tripartita) and Cassigerinella are rare or absent, whereas cooler middle latitude species (e. g., "Globigerina" euapertura), and cooler province indicators of Globorotaloides, Subbotina angiporoides, Globigerina, and the tenuitellids increase during the early Oligocene.

In general, middle- and high-latitude taxa immigrated into low latitudes and replaced low-latitude groups during the latest Eocene to earliest Oligocene, resulting in the homogeneous Oligocene faunas through a broad latitudinal range (Haq et al., 1977; Boersma and Premoli Silva, 1986; Premoli Silva and Boersma, 1988, 1989). Compared with the faunas of the Atlantic Ocean, the late Eocene to earliest Oligocene assemblages at Site 841 contained nearly equal numbers of cool-and warm-water species, an attribute of the warm middle latitude fauna. The faunas resembling those of Site 841 have been reported from Sites 828 and 829 in Leg 134 (Collot, Greene, Stokking, et al., 1992), and Sites 286 and 288 in Leg 30 (Andrews, Packham, et al., 1975). This similarity in faunal composition suggests that these sites belong to the same bioprovince (Fig. 7). On the other hand, Sites $592,593,277,281$, and 282 include high-latitude assemblages of planktonic foraminifers, consisting of Globigerinatheka index index, Subbotina angiporoides, S. linaperta, Chiloguembelina cubensis, Pseudohastigerina micra (= Globanomalina micra), Tenuitella (= Turborotalia) gemma, Turborotalia insolita, Globorotaloides suteri, Turborotalia munda, "Globigerina" ampliapertura, and Globigerina brevis (= Subbotina brevis) without such warm-water species as Globoquadrina tripartita (= Dentoglobigerina tripartita), Turborotalia pseudoampliapertura, T. increbescens (Jenkins, 1975; Jenkins and Srinivasan, 1985), with the exception of Turborotalia cerroazulensis found at Site 277 (Keller, 1983). Sites 277/281 are located within the temperate (cool subtropical) and Sites 282/593/ 592 lie within the subantarctic biogeographic bioprovince in modern oceans (Fig. 7). During the Eocene and Oligocene when they were 
Table 3. List of planktonic groups used in this paper (after Premoli Silva and Boersma, 1988).

\begin{tabular}{|c|c|}
\hline Group & Species \\
\hline 1. & $\begin{array}{l}\text { Acarinina spinulosa lineage } \\
\text { Acarinina densa (Cushman) } \\
\text { Acarinina bullbrooki (Bolli) }\end{array}$ \\
\hline 2. & $\begin{array}{l}\text { Heterohelicids } \\
\text { Cassigerinella chipolensis (Cushman and Ponton) }\end{array}$ \\
\hline 3. & $\begin{array}{l}\text { Catapsydrax } \\
\text { Catapsydrax africamus (Blow and Banner) } \\
\text { Catapsydrax dissimilis (Cushman and Bermúdez) } \\
\text { Catapsydrax globiformis (Blow and Banner) } \\
\text { Catapsydrax martini (Blow and Banner) } \\
\text { Catapsydrax pera (Todd) } \\
\text { Catapsydrax unicavus Bolli, Loeblich, and Tappan }\end{array}$ \\
\hline 4. & $\begin{array}{l}\text { Biserial heterohelicids } \\
\text { Chiloguembelina cubensis (Palmer) } \\
\text { Chiloguembelina martini (Pijpers) }\end{array}$ \\
\hline 5. & $\begin{array}{l}\text { Dentoglobigerina } \\
\text { Dentoglobigerina galavisi (Bermúdez) }\end{array}$ \\
\hline 6. & $\begin{array}{l}\text { Dentoglobigerina tripartita group } \\
\text { Dentoglobigerina sellii (Borsetti) } \\
\text { Dentoglobigerina tapuriensis (Blow and Banner) } \\
\text { Dentoglobigerina tripartita Koch }\end{array}$ \\
\hline 7. & $\begin{array}{l}\text { "Globigerina" ampliapertura Bolli } \\
\text { "Globigerina" ampliapertura Bolli } \\
\text { Turborotalia increbescens (Bandy) }\end{array}$ \\
\hline 8. & $\begin{array}{l}\text { Globigerina s. str. } \\
\text { Globigerina angustiumbilicata } \text { Bolli } \\
\text { Globigerina officinalis Subbotina } \\
\text { Globigerina ouachitaensis ouachitaensis Howe and Wallace } \\
\text { Globigerina senilis Bandy }\end{array}$ \\
\hline 9. & $\begin{array}{l}\text { Large globigerines } \\
\text { "Globigerina" euapertura Jenkins } \\
\text { "Globigerina" pseudovenezuelana (Blow and Banner) }\end{array}$ \\
\hline 10. & $\begin{array}{l}\text { Globigerinatheka } \\
\text { Globigerinatheka index (Finlay) } \\
\text { Globigerinatheka mexicana barri Brönnimann } \\
\text { Globigerinatheka mexicana mexicana (Cushman) } \\
\text { Globigerinatheka cf. semiinvoluta (Keijzer) } \\
\text { Globigerinatheka subconglobata luterbacheri Bolli } \\
\text { Globigerinatheka tropicalis (Blow and Banner) }\end{array}$ \\
\hline 11. & $\begin{array}{l}\text { Globorotaloides } \\
\text { Globorotaloides suteri Bolli }\end{array}$ \\
\hline
\end{tabular}

located at about $50^{\circ}$ to $70^{\circ} \mathrm{S}$, the planktonic foraminifer assemblages of the two groups are very similar, suggesting that the oceanographic front between the biogeographic provinces had not yet developed (Murphy and Kennett, 1986; Kennett and von der Borch, 1986).

However, the differences between the planktonic faunal assemblages of the northern (286/288/829/828/841) and southern (277/281/ 282/593/592) sites are distinct, and each assemblage represents the tropical-subtropical bioprovince and the temperate-subantarctic bioprovince, respectively, during the late Eocene to early Oligocene. Presumably, the oceanographic boundary was located at about $40^{\circ} \mathrm{S}$ latitude between Sites 592 and 841 (Fig. 7).

The first high-latitude, surface-water communication between the southern Indian and South Pacific oceans occurred in the latest Eocene across the shallow, subsiding South Tasman Rise. This opening permitted the passage of cool Indian Ocean waters into the South Pacific, leading to a cooling of waters in the South Pacific and an initial decoupling of the warm-subtropical gyre from the Southern Ocean (Kennett, 1977; Kennett and von der Borch, 1986; Murphy and Kennett, 1986). The presence of two latitudinal bioprovinces in the late Eocene to early Oligocene, therefore, implies that the opening of this seaway and the subsequent influx of the cool Circum-Antarctic Current occurred sometime before the late Eocene (about $37 \mathrm{Ma}$ ). Common to high abundances of cool-water species such as Globorotaloides suteri, Catapsydrax, Tenuitella, and small globigerinids at Site 841 may indicate the influx of a cold-water spike reaching into fairly northern regions of the subtropical bioprovince.

\begin{tabular}{|c|c|}
\hline Group & Species \\
\hline 12. & $\begin{array}{l}\text { Hantkeninids } \\
\text { Hantkenina alabamensis Cushman }\end{array}$ \\
\hline 13. & $\begin{array}{l}\text { Weakly muricocarinate morozovellids } \\
\text { Morozovella spinulosa (Cushman) }\end{array}$ \\
\hline 14. & $\begin{array}{l}\text { Planorotalites } \\
\text { Planorotalites renzi (Bolli) }\end{array}$ \\
\hline 15. & $\begin{array}{l}\text { Pseudohastigerina } \\
\text { Pseudohastigerina barbadoensis Blow } \\
\text { Pseudohastigerina micra (Cole) } \\
\text { Pseudohastigerina wilcoxensis (Cushman and Ponton) }\end{array}$ \\
\hline 16. & $\begin{array}{l}\text { Subbotina linaperta group } \\
\text { Subbotina angiporoides (Hornibrook) } \\
\text { Subbotina brevis Jenkins } \\
\text { Subbotina linaperta (Finlay) } \\
\text { Subbotina utilisindex (Jenkins and Orr) }\end{array}$ \\
\hline 17. & $\begin{array}{l}\text { Low-spired subbotinids } \\
\text { Subbotina eocaena (Gümbel) } \\
\text { Subbotina yeguaensis (Weinzierl and Applin) }\end{array}$ \\
\hline 18. & $\begin{array}{l}\text { High-spired subbotinids } \\
\text { Subbotina gortanii (Borsetti) } \\
\text { Subbotina corpulenta (Subbotina) }\end{array}$ \\
\hline 19. & $\begin{array}{l}\text { Turborotalia cerroazulensis lineage } \\
\text { Turborotalia centralis (Cushman and Bermúdez) } \\
\text { Turborotalia cerroazulensis cerroazulensis (Cole) } \\
\text { Turborotalia cerroazulensis cocoaensis (Cushman) }\end{array}$ \\
\hline 20. & $\begin{array}{l}\text { Globigerinella } \\
\text { Globigerinella obesa (Bolli) }\end{array}$ \\
\hline 21. & $\begin{array}{l}\text { Paragloborotalia opima group } \\
\text { Paragioborotalia opima nana (Bolli) }\end{array}$ \\
\hline 22. & $\begin{array}{l}\text { Tenuitella } \\
\text { Tenuitella munda Jenkins } \\
\text { Tenuitella postcretacea (Myatliuk) }\end{array}$ \\
\hline
\end{tabular}

\section{CONCLUSIONS}

The lowermost sedimentary sequence, Unit V (549-605 mbsf), at Site 841 is a $56-m$-thick sequence of middle Eocene to lower Oligocene volcanic sandstone with thin interbeds of claystone. This unit is overlain unconformably by a lower middle Miocene sequence, referable to Zones N8 and N9, with a hiatus spanning approximately 13 m.y.

The middle Eocene fauna (Core 135-841B-47R) includes Acarinina densa, A. spinuloinflata, Morozovella spinulosa, and Truncorotaloides topilensis, with additional species of Turborotalia cerroazulensis cerroazulensis, Catapsydrax howei, Globigerinatheka mexicana mexicana, and Planorotalites renzi.

This assemblage is referable to Zone P14 or older. Late Eocene faunas (from Cores $135-841 \mathrm{~B}-46 \mathrm{R}$ to $-44 \mathrm{R}$ ) are characterized by species of Globigerinatheka, Hantkenina, subspecies of Turborotalia cerroazulensis, and Subbotina linaperta. The co-occurrence of $T$. cerroazulensis cocoaensis and Globigerinatheka subconglobata luterbacheri indicates Zones P15 to P16. The early Oligocene faunas (from Cores 135-841B-43R to -41R) include large numbers of Pseudohastigerina, Chiloguembelina, Dentoglobigerina, Subbotina, Globigerina, and Catapsydrax, indicative of Zone P18.

Two hiatuses are recognized in the Eocene interval of Site 841. An unconformity is present between the middle and upper Eocene, with a stratigraphic gap spanning approximately 1.8 m.y. at least, whereas a small hiatus separates the upper Eocene sequence from the lower Oligocene, with the uppermost Eocene Zone P17 (about 1 m.y. interval) missing. 


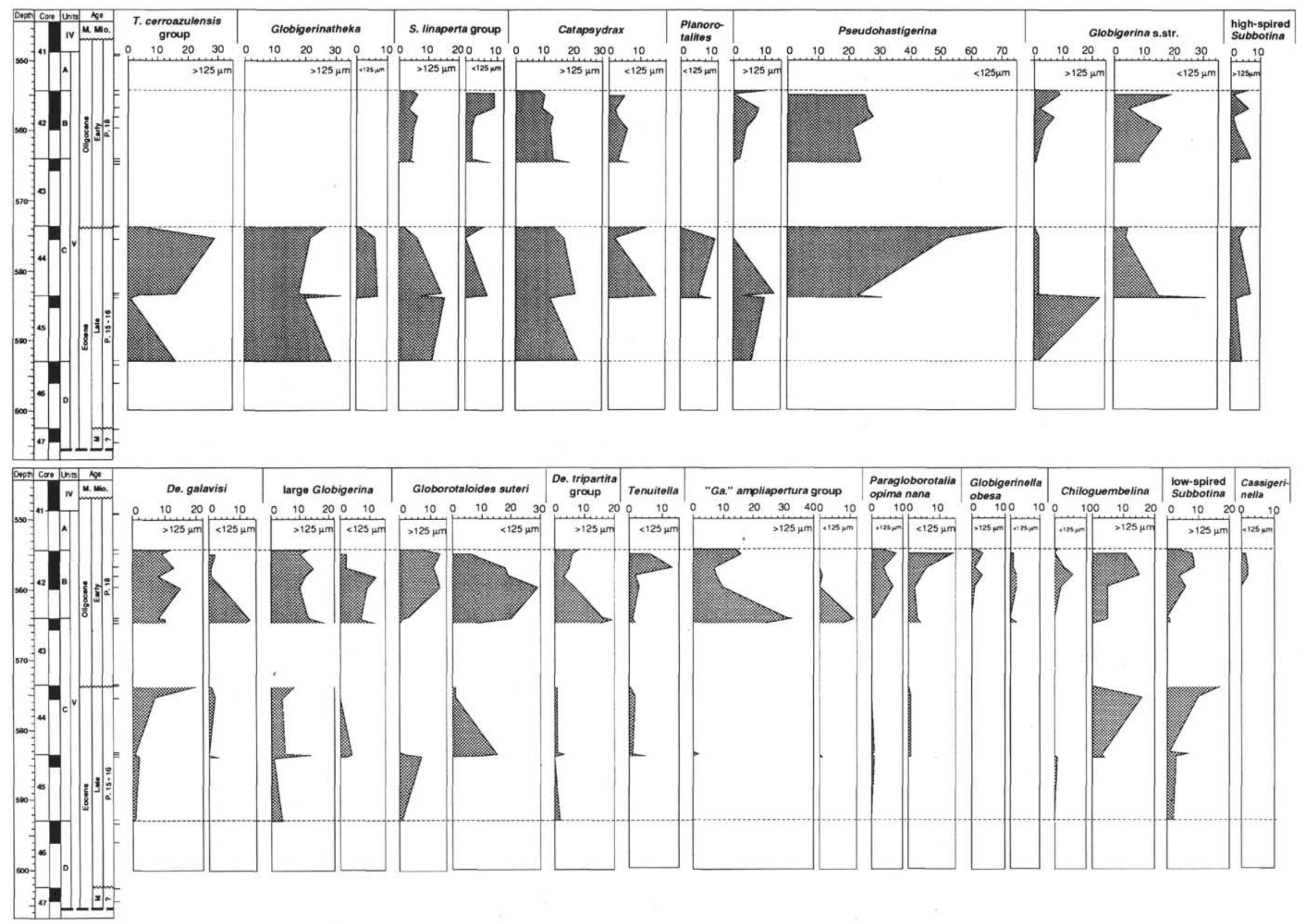

Figure 6. Abundance percentage curves of groups of late Eocene to early Oligocene planktonic foraminifers in Hole $841 \mathrm{~B}$. Results of coarse fraction (>125 $\mu \mathrm{m})$ analyses are shown on the left, and data on fine fraction $(<125 \mu \mathrm{m})$ analyses are on the right. Small samples $(<100$ specimens) were not included in this figure. 
A

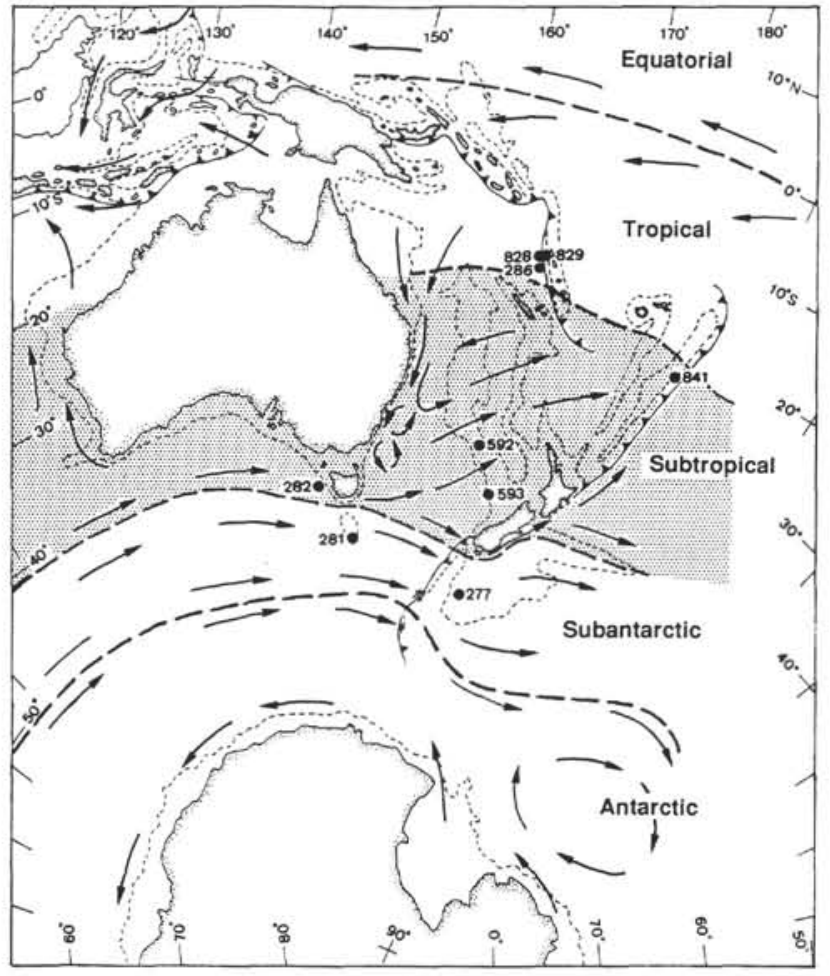

B

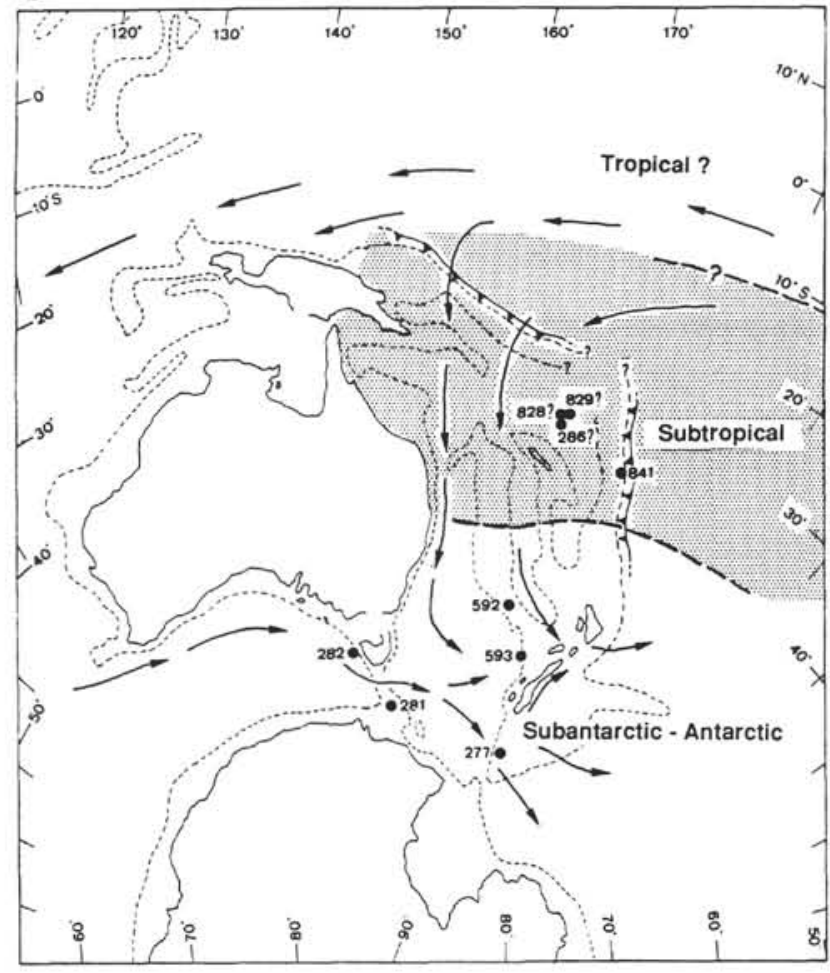

Figure 7. Present-day and Paleogene (late Eocene to early Oligocene) southwest Pacific surface-water circulation patterns. A. The modern ocean summarized from Edwards (1975), Murphy and Kennett (1986), and Kennett and von der Borch (1986). B. Proposed model for late Eocene to early Oligocene circulation pattern. The location of continents is based on Edwards (1975) and the circulation patterns of currents are modified from Murphy and Kennett (1986). Dotted areas show the subtropical biogeographic province.

The dominant taxa in the upper Eocene sequence are Catapsydrax $(>12 \%)$ and Globigerinatheka $(>18 \%)$. The lower Oligocene faunas in the coarse fractions $(>125 \mu \mathrm{m})$ are dominated by large globigerinid groups, along with less common Catapsydrax, Dentoglobigerina, "Globigerina" ampliapertura group, and Globorotaloides. Abundances of these species generally exceed $10 \%$. The most characteristic feature in the Oligocene is a rapid increase of the " $G$." ampliapertura group in the coarse fractions. Pseudohastigerina dominates ( $>20 \%)$ assemblages in the fine fractions $(<125 \mu \mathrm{m})$ throughout the upper Eocene to lower Oligocene.

In the middle to late Eocene, the presence of tropical-subtropical Indo-Pacific larger foraminifers indicates that Site 841 belongs to a tropical-subtropical bioprovince, but in the late Eocene the planktonic faunal assemblages began to include the cool-water taxa Catapsydrax, Globorotaloides, and Globigerina. In the Oligocene sequence, such typical warm-water indicators as Dentoglobigerina tripartita and Cassigerinella are rare or absent, whereas middle-latitude species (e.g., "Globigerina" euapertura and "G." ampliapertura), and cooler province indicators increase. These characteristics imply that the Paleogene assemblages at Site 841 are referable to warm middlelatitude faunas.

The late Eocene faunal composition of Site 841 differs from that of more southern sites in the southwest Pacific Ocean. These differences suggest that the biogeographical boundary was located at about $40^{\circ} \mathrm{S}$ latitude, between Sites 592 and 841 . The presence of two distinct assemblages suggests that the opening of a seaway between the Pacific and Indian oceans and subsequent influx of the cool Indian Ocean current occurred before the late Eocene (about $37 \mathrm{Ma}$ ).

\section{SPECIES LIST AND TAXONOMIC NOTES}

Species are listed in alphabetical order by genus. The generic and specific concepts and the species groups are those used by Premoli Silva and Boersma $(1988,1989)$ and Spezzaferri and Premoli Silva (1991); however, the taxo-

nomic positions of several species classification are retained as those reflecting our own concept in this paper. Reference is made to the most reliable illustrations reported in the literature available. All the specimens are deposited in the microfossil collection of the Department of Earth Sciences, Yamagata University, Yamagata, Japan.

Acarinina densa (Cushman) (Plate 1, Figs. 1-3). Pulvinulina crassata var. densa Cushman, 1925a, p. 300. Redrawn figures in Cifelli, 1972, pp. 157-159, text-figs. la-c.

Acarinina spinuloinflata (Bandy). Globigerina spinuloinflata Bandy, 1949, p. 122, pl. 23, figs. 1a-c.

Cassigerinella chipolensis (Cushman and Ponton) (Plate 1, Figs. 12-14). Cassidulina chipolensis Cushman and Ponton, 1932, p. 98, pl. 15, figs. 2a-c. Cassigerinella chipolensis (Cushman and Ponton) in Bolli, 1957b, p. 108, pl. 22, fig. 3 .

Catapsydrax africanus (Blow and Banner) (Plate 3, Figs. 4-9).

Globigerinita africana Blow and Banner, 1962, pp. 105-106, pl. XV, figs. A-C, fig. 11, i-iv.

Catapsydrax dissimilis (Cushman and Bermúdez). Globigerina dissimilis Cushman and Bermúdez, 1937, pp. 25-26, pl. 3, figs. 4-6. Catapsydrax dissimilis (Cushman and Bermúdez) in Bolli, Loeblich, and Tappan, 1957, p. 36, pl. 7, figs. 6a-c and 7a-8c. Globigerinita dissimilis dissimilis (Cushman and Bermúdez) in Blow and Banner, 1962, pp. 106-107, pl. XIV, fig. D. Globigerinita dissimilis ciperoensis Blow and Banner, 1962, pp. 107-108, pl. XIV, figs. A-C.

Catapsydrax globiformis (Blow and Banner) (Plate 2, Figs. 27-29). Globigerinita globiformis Blow and Banner, 1962, pp. 108-109, pl. XIV, figs. S-U.

Catapsydrax howei (Blow and Banner) (Plate 3, Figs. 1-3). Globigerinita howei Blow and Banner, 1962, pp. 109-110, pl. XIV, figs. P-R, text-figs. $11, \mathrm{x}$-xiv.

Catapsydrax martini (Blow and Banner) (Plate 3, Fig. 13). Globigerinita martini martini Blow and Banner, 1962. pp. 110-111, pl. XIV, fig. O. Globigerinita martini scandretti Blow and Banner, 1962, pp. 111-112, pl. XIV, figs. V-X.

Catapsydrax pera (Todd) (Plate 3, Figs. 10-12). Globigerina pera Todd, 1957. p. 301, pl. 70, figs. 10-11. Globigerinita pera (Todd) in Blow and Banner, 1962, pp. 112-113, pl. XIV, figs. E-H. 
Catapsydrax unicavus Bolli, Loeblich, and Tappan (Plate 3, Figs. 14-15). Bolli, Loeblich, and Tappan, 1957, p. 37, pl. 7, figs. 9a-c. Globigerinita unicava unicava (Bolli, Loeblich, and Tappan) in Blow and Banner, 1962, pp. 113-114, pl. XIV, figs. M-N. Globigerinita unicava primitiva Blow and Banner, 1962, pp. 113-114, pl. XIV, figs. M-N.

Chiloguembelina cubensis (Palmer) (Plate 1, Fig. 30-31). Gïembelina cubensis Palmer, 1934, p. 74, text-figs. 1-6. Chiloguembelina cubensis (Palmer) in Beckmann, 1957, p. 89, pl. 21, fig. 21, text-fig. 14, figs. 5-8.

Chiloguembelina martini (Pijpers) (Plate 1, Fig. 32). Textularia martini Pijpers, 1933, p. 57, figs. 6-10. Chiloguembelina martini (Pijpers) in Beckmann, 1957 , p. 89 , pl. 21 , fig. 14 , text-figs. 4 , figs. $4,9-11,14-18$, and $20-23$.

Dentoglobigerina galavisi (Bermúdez) (Plate 5, Figs. 10-12). Globigerina galavisi Bermúdez, 1961, pp. 1183-1184, pl. IV. fig. 3; Blow, 1979, p. 121, pl. 5, figs. 1-3. Globigerina yeguaensis yeguaensis Weinzierl and Applin in Blow and Banner, 1962, pp. 99-100, pl. XIII, figs. H-M.

Dentoglobigerina sellii (Borsetti) (Plate 5, Figs. 7-9). Globoquadrina sellii Borsetti, 1959, p. 209, pl. 1, figs. 3a-d. Globigerina oligocaenica Blow and Banner in Blow and Banner, 1962, pp. 88-89, pl. X, figs. G and L-N.

Dentoglobigerina tapuriensis (Blow and Banner) (Plate 5, Figs. 4-6). Globigerina tripartita tapuriensis Blow and Banner, 1962, pp. 97-98, pl. X, figs. $\mathrm{H}-\mathrm{K}$.

Dentoglobigerina tripartita Koch (Plate 5, Figs. 1-3). Globigerina bulloides d'Orbigny var. tripartita Koch, 1926, p. 746, text-figs. 21 a-b. Globigerina rohri Bolli, 1957b, pp. 109 and 141-144, pl. 23, figs. 1a-4b. Globigerina tripartita tripartita Koch in Blow and Banner, 1962, pp. 96-97 and 141-144, pl. X, figs. A-F.

"Globigerina" ampliapertura Bolli (Plate 4, Figs. 1-6). Globigerina ampliapertura Bolli, 1957 b, p. 108, pl. 22, figs. 5-7. The distinct feature of this species is its large, distinctly high-arched aperture. However, the shape and position of aperture vary from asymmetrical and slightly extraumbilical-umbilical (Globorotalia-type) to symmetrical and umbilical (Globigerina-type), which results in difficulties of generic attribution for this species. Globigerina pseudoampliapertura proposed by Blow and Banner (1962) is distinguished from $G$. ampliapertura by the presence of a smooth, finely perforate wall. G. pseudoampliapertura is a low-latitude index for the Oligocene age (Premoli Silva and Boersma, 1988, 1989). Samples of Hole $841 \mathrm{~B}$ yielded many specimens referable in morphology to $G$. pseudoampliapertura, but these forms were recognized as " $G$." ampliapertura in this paper because of the possession of a slightly rough and pitted wall surface.

Globigerina angustiumbilicata Bolli (Plate 4, Figs. 25-27). Globigerina ciperoensis angustiumbilicata Bolli, 1957b, p. 109, pl. 22, figs. 12-13.

"Globigerina" euapertura Jenkins (Plate 4, Figs. 10-12). Globigerina euapertura Jenkins, 1960, p. 351, pl. 1, figs. 8a-c. Globigerina reticulata Stache in Hornibrook, 1961 , p. 146, text-figs. 4b-c, Jenkins, 1971, p. 147, pl. 15, figs. 457-461, pl. 16, fig. 462. Globigerina ampliapertura euapertura (Jenkins) in Blow and Banner, 1962, p. 84, pl. XI, figs. E-G. Globigerina prasaepis in Blow, 1969 , pp. 321 and $382-383$, pl. 10, fig. 13, pl. 18, figs. $3-7$. This species differs from "G." ampliapertura in possessing more depressed later chambers and in the low-arched, more slit-like aperture. Because some specimens display the slightly extraumbilical-umbilical apertural position, its generic attribution is uncertain. Although Globigerina prasaepis Blow is distinguished from " $G$." euapertura by having a restricted aperture and a well-developed apertural lip (Blow, 1969), the specimens from this core include forms with or without a distinct apertural lip or rim and the apertural width is very variable. These features are found among specimens in Australia and New Zealand sections (Jenkins, 1971; Chaproniere, 1981). Therefore, it is difficult to separate G. prasaepis from "G." euapertura by the criteria proposed by Blow (1969), and both are considered synonymous in this paper.

Globigerina officinalis Subbotina (Plate 5, Figs. 16-18). Subbotina, 1953, p. 78 , pl. 11, figs. 1-7; Blow and Banner, 1962, p. 88, pl. IX, figs. A-C.

Globigerina praebulloides Blow (Plate 5, Figs. 25-27). Blow, 1959, pp. 180-181, pl. 8, figs. $47 \mathrm{a}-\mathrm{c}$, pl. 9, fig. 48. Globigerina praebulloides praebulloides Blow and Banner, 1962, pp. 92-93, pl. IX, figs. O-Q. Globigerina praebulloides leroyi Blow and Banner, 1962, p. 93, pl. IX, figs. R-T. Globigerina praebulloides occlusa Blow and Banner, 1962, pp. 93-94, pl. IX, figs. V-W.

"Globigerina" pseudovenezuelana Blow and Banner (Plate 5, Figs. 22-24). Globigerina yeguaensis pseudovenezuelana, Blow and Banner, 1962, pp. 100-101, pl. XI, figs. J-L, N, and O. This species was classified by Blow (1979) as belonging to the genus Dentoglobigerina, which is characterized by possessing a triangular-shaped, portical-umbilical tooth. Because the specimens with these teeth were not found in samples recovered from Site 841 , its generic attribution is retained in quotation marks.

Globigerina senilis Bandy (Plate 4, Figs. 13-15). Globigerina ouachitaensis Howe and Wallace var. senilis Bandy, 1949, p. 121, pl. 22, figs. 5a-c. Globigerina senilis Bandy in Blow and Banner, 1962, pp. 95-96, pl. XI, figs. R-U,

Globigerinatheka index index (Finlay) (Plate 2, Figs. 22-24). Globigerinoides index Finlay, 1939, p. 125, pl. 14, figs. 85-88. Globigerapsis index (Finlay) in Bolli, 1957a, p. 165, pl. 36, figs. 14-18. Globigerinatheka index index (Finlay) in Bolli, 1972, pp. 124-126, text-figs. 51-57 and 63-64, pl. 1, figs. $1-4$ and 6-7.

Globigerinatheka index tropicalis (Blow and Banner) (Plate 2, Figs. 4-9). Globigerapsis tropicalis Blow and Banner, 1962, pp. 124-125, pl. XV, figs. D-F; Globigerinatheka index tropicalis (Blow and Banner) in Bolli, 1972 , pp. $127-128$, text-figs. 58-60, pl. 3, figs. 1-24.

Globigerinatheka mexicana barri Brönnimann (Plate 2, Figs. 10-12 and 25-26). Globigerinatheka barri Brönnimann, 1952, p. 27, text-figs. 3a-c; Globigerinatheka mexicana barri Brönnimann in Bolli, 1972, p. 128, pl. 2, figs. 8-20, text-figs. 21-26.

Globigerinatheka mexicana mexicana (Cushman) (Plate 2, Figs. 13-15). Globigerina mexicana Cushman, 1925c, p. 6, pl. 1, fig. 8. Globigerapsis mexicana (Cushman) in Blow and Saito, 1968, pp. 357-360, text-figs. 1-4. Globigerinatheka mexicana mexicana (Cushman) in Bolli, 1972, p. 129 , figs. 1-11, pl. 2, figs. $1-5$.

Globigerinatheka cf. semiinvoluta (Keijzer), 1945 (Plate 2, Figs. 19-21). Globigerinatheka semiinvoluta is characterized by its hemispherical final chamber, which embraces nearly one-half of the earlier test and a higharched circular aperture with distinct rim. This species is easily distinguished from other species of Globigerinatheka by its embracing final chambers, tightly coiled initial test, and fairly shallow and indistinct sutures. Specimens from this core, however, differ from typical forms in lacking large circular sutural apertures. Premoli Silva and Boersma (1988) demonstrated that $G$. semiinvoluta never exhibits well-developed supplementary apertures, and it is always smaller in size at middle latitudes than at low latitudes in the Atlantic province. These small aperture types are identified as $G$. cf. semiinvoluta in this paper.

Globigerinatheka subconglobata luterbacheri Bolli (Plate 2, Figs. 1-3). Bolli, 1972, pp. 132-133, text-figs. 47-50, pl. 1, figs. 17 and 22-25.

Globigerinella obesa (Bolli) (Plate 1, Figs. 36-38). Globorotalia obesa Bolli, 1957 b, p. 119 , pl. 29 , figs. 2-3.

Globorotaloides suteri Bolli (Plate 1, Figs. 15-17). Bolli, 1957b, p. 117, pl. 27, figs. 9-13; Bolli, 1957a, p. 166, pl. 37, figs. 10-12; Blow and Banner, 1962 , pp. 122-123, pl. XIII, figs. N-P.

Globorotaloides permicrus (Blow and Banner). Globorotalia (Turborotalia) permicra Blow and Banner, 1962, p. 120, pl. XII, figs. N-P.

Hantkenina alabamensis Cushman (Plate 2, Figs. 16-18). Cushman, 1925b, p. 3, fig. 1, pl. 1, figs. 1-6, pl. 2, fig. 5; Bolli, Loeblich, and Tappan, 1957 , p. 26, pl. 2, fig. 8; Blow and Banner, 1962, pp. 126-127, pl. XVI, figs. C, $\mathrm{D}, \mathrm{J}$, and $\mathrm{K}$.

Morozovella spinulosa (Cushman) (Plate 1, Figs. 2-6). Globorotalia spinulosa Cushman, 1927, p. 114, pl. 23, fig. 4; Bolli, 1957a, p. 168, pl. 38, fig. 6-7. Globorotalia (Morozovella) spinulosa spinulosa Cushman in Blow, 1979, pp. 1013-1015, pl. 182, figs. 1-4, pl. 197, figs. $1-6$.

Paragloborotalia opima nana (Bolli) (Plate 1, Figs. 39-41). Globorotalia opima nana Bolli, 1957b, p. 118, pl. 28, figs. 3a-c. Globorotalia (Turborotalia) opima nana Bolli in Blow and Banner, 1962, pp. 119-120, pl. XIII, figs. Q-S; Toumarkine and Luterbacher, 1985, pp. 202-203, text-fig. 26, figs. 15-20.

Planorotalites renzi (Bolli) (Plate 1, Figs. 9-11). Globorotalia renzi Bolli, 1957a, p. 168 , pl. 38 , fig. 3.

Pseudohastigerina barbadoensis Blow (Plate 1, Figs. 28-29). Blow, 1969, pp. 376 and $409-410$, pl. 53, figs. 7-9, pl. 54, figs. 1-3. Pseudohastigerina naguewichiensis barbadoensis Blow, 1979, p. 763, pp. 1190-1191, pl. 246 , figs. 2 and $6-7$.

Pseudohastigerina danvillensis (Howe and Wallace) (Plate 1, Figs. 22-23). Nonion danvillensis Howe and Wallace, 1932, p. 51, pl. 9, figs. 3a-b.

Pseudohastigerina micra (Cole) (Plate 1, Figs. 24-27). Nonion micrus Cole, 1927 , p. 22, pl. 5, fig. 12. Hastigerina micra (Cole). Bolli, 1957a, p. 161, pl. 35, figs. 1a-2b. Pseudohastigerina micra (Cole) in Banner and Blow, 1959, pp. 19-20, figs. $4 \mathrm{~g}-\mathrm{i}$.

Pseudohastigerina wilcoxensis (Cushman and Ponton) (Plate 1, Figs. 18-21). Nonion wilcoxensis Cushman and Ponton, 1932, p. 64, pl. 8, fig. 11. Pseudohastigerina wilcoxensis (Cushman and Ponton) in Berggren et al., 
1967, pp. 278-280, text-figs. 2a-v, text-fig. 3, figs. 2a-5c, text-fig. 4, figs. $2 \mathrm{a}-5 \mathrm{c}$.

Subbotina angiporoides (Hornibrook) (Plate 5, Figs. 28-30). Globigerina angiporoides Hornibrook, 1965, pp. 834-838, figs. 1-2.

Subbotina brevis (Jenkins) (Plate 4, Figs. 16-18). Globigerina brevis Jenkins, 1966, pp. 1100-1102, text-figs. 7-58 to -63 .

Subbotina corpulenta (Subbotina) (Plate 4, Figs. 19-20). Globigerina corpulenta Subbotina, 1953, pp. 76-78, pl. IX, figs. 5-7, pl. X, figs. 2-4. G. corpulenta is distinguished from $G$. eocaen $a$ by its somewhat rapidly enlarging chambers and its high-spired coiling. It differs from $G$. gortanii in having a low-spired coiling and more loosely arranged globular chambers. This species is characterized by morphologic variations with abnormal or bulla-like last chambers, as shown by Subbotina $(1953,1971)$ and Stainforth and Lamb (1981).

Subbotina eocaena (Gümbel) (Plate 5, Figs. 19-21). Globigerina eocaena Gümbel, 1868, p. 662, pl. 2, fig. 109; Subbotina, 1953, pl. VI, fig. 5, pl. VII, fig. 1. Globigerina (Subbotina) eocaena Gümbel in Hang and Lindenberg, 1966, pp. 342-358, figs. $1-4$.

Subbotina gortanii (Borsetti) (Plate 4, Figs. 28-30). Catapsydrax gortanii Borsetti, 1959, pp. 205-212, pl. I, fig. 1. Globigerina turritilina turritilina in Blow and Banner, 1962, pp. 98-99. pl. XIII, figs. D-G. Globigerina turritilina praeturritilina in Blow and Banner, 1962, p. 99, pl. 13, figs. A-C.

Subbotina linaperta (Finlay) (Plate 4, Figs. 22-24). Globigerina linaperta Finlay, 1939, p. 125, pl. 13, figs. 54-56. Globigerina linaperta Finlay in Hornibrook, 1958, pp. 33-34, pl. 1, figs. 19-21.

Subbotina utilisindex (Jenkins and Orr). Globigerina utilisindex Jenkins and Orr, 1973, pp. 133-135, pl. 1, figs. 1-3.

Subbotina yeguaensis (Weinzierl and Applin) (Plate 5, Figs. 13-15). Globigerina yeguaensis Weinzierl and Applin, 1929, p. 408, pl. 43, figs. la-b; Bolli, 1957a, p. 163, pl. 35, figs. 14a-15c. Globigerina yeguaensis yeguaensis Weinzierl and Applin in Blow and Banner, 1962, pp. 99-100. pl. XIII, figs. H, J, and $\mathrm{K}-\mathrm{M}$.

Tenuitella munda (Jenkins) (Plate 1, Figs. 33-35). Globorotalia (Turborotalia) munda Jenkins, 1966, pp. 1121-1122, text-fig. 14, figs. 126-133.

Tenuitella postcretacea (Myatliuk). Globigerina postcretacea Myatliuk, 1950, p. 280, pl. 4, fig. 3; Subbotina, 1953, pp. 60-61, pl. 2, figs. 16-20. Globorotalia (Turborotalia) postcretacea (Myatliuk) in Blow and Banner, 1962, pp. 120-121, pl. XII, figs. G-J.

Truncorotaloides topilensis (Cushman) (Plate 1, Figs. 7-8). Globigerina topilensis Cushman, 1925c, p. 7, pl. 1, fig. 9; Bolli, 1957a, p. 170, pl. 39 , figs. 13-16b.

Turborotalia centralis (Cushman and Bermúdez) (Plate 3, Figs. 16-18). Globorotalia centralis Cushman and Bermúdez, 1937, pp. 26-27, pl. 2, figs. 62 and 64-65; Bolli, Loeblich, and Tappan, 1957, p. 41, pl. 10, figs. 4a-c.

Turborotalia cerroazulensis cerroazulensis (Cole) (Plate 3, Figs. 19-24), Globigerina cerroazulensis Cole, 1928, p. 17, pl. 1, figs. 11-13. Globorotalia cerroazulensis cerroazulensis (Cole) in Toumarkine and Bolli, 1970. p. 144, pl. 1, figs. 19-24.

Turborotalia cerroazulensis cocoaensis (Cushman) (Plate 3, Figs. 25-30). Globorotalia cocoaensis Cushman, 1928, p. 75, pl. 10, figs. 3a-c; Bolli, 1957a, pp. 169-170, pl. 39, figs. 5a-7b.

Turborotalia increbescens (Bandy) (Plate 4, Figs. 7-9). Globigerina increbes cens Bandy, 1949, pp. 120-121, pl. 23, fig. 3. Globorotalia (Turborotalia) increbescens (Bandy) in Blow and Banner, 1962, pp. 118-119, pl. XIII, figs. T-V.

\section{ACKNOWLEDGMENTS}

The authors thank T. Saito for reviewing the manuscript and giving advice on taxonomic problems. The authors are deeply indebted to $\mathrm{K}$. Mukaiyama, R. Chinone, M. Tamura, A. Kurosawa, and T. Sato, all of the Department of Earth Sciences, Yamagata University, for SEM operation and printing photographs. G.C. Chaproniere publishes with the permission of the Executive Director, Bureau of Mineral Resources, Canberra.

\section{REFERENCES}

Adams, C.G., 1970. A reconsideration of the East Indian Letter Classification of the Tertiary. Bull. Br. Mus. (Nat. Hist.), Geol., 19:87-137.

\footnotetext{
Abbreviations for names of organizations and publication titles in ODP reference lists follow the style given in Chemical Abstracts Service Source Index (published by American Chemical Society).
}

1984. Neogene larger foraminifera, evolutionary and geological events in the context of datum planes. In Ikebe, N., and Tsuchi, R. (Eds.), Pacific Neogene Datum Planes: Contributions to Biostratigraphy and Chronology: Tokyo (Univ. of Tokyo Press), 47-67.

Andrews, J.E., Packham, G., et al., 1975. Init. Repts. DSDP, 30: Washington (U.S. Govt. Printing Office).

Aubry, M.-P., Berggren, W.A., Kent, D.V., Flynn, J.J., Klitgord, K.D., Obradovich, J.D., and Prothero, D.R., 1988. Paleogene geochronology: an integrated approach. Paleoceanography, 3:707-742.

Bandy, O.L., 1949. Eocene and Oligocene foraminifera from Little Stave Creek, Clarke County, Alabama. Bull. Am. Paleontol., 32:1-210.

Banner, F.T., and Blow, W.H., 1959. The classification and stratigraphical distribution of the Globigerinaceae, Part 1. Palaeontology, 2:1-27.

Beckmann, J.P., 1957. Chiloguembelina Loeblich and Tappan and related Foraminifera from the lower Tertiary of Trinidad, B.W.I. Bull.-U.S. Nat. Mus., 215:83-95.

Berggren, W.A., Kent, D.V., and Flynn, J.J., 1985. Jurassic to Paleogene: Part 2. Paleogene geochronology and chronostratigraphy. In Snelling, N.J. (Ed.), The Chronology of the Geological Record. Geol. Soc. London Mem., 10:141-195.

Berggren, W.A., and Miller, K.G., 1988. Paleogene tropical planktonic foraminiferal biostratigraphy and magnetobiochronology. Micropaleontology, $34: 362-380$.

Berggren, W.A., Olsson, R.K., and Reyment, R.A., 1967. Origin and development of the foraminiferal genus Pseudohastigerina Banner and Blow, 1959. Micropaleontology, 13:265-288.

Bermúdez, P.J., 1961. Contribuciön al estudio de las Globigerinidae de la regiön Caribe-Antillana (Paleocene-Recente). Mem. III Congr. Geol. Venezolano, Soc. Geol. Venez., Bol. Geol., Publ. Espec., 3:1119-1393.

Blow, W.H., 1959. Age, correlation and biostratigraphy of the upper Tocuyo (San Lorenzo) and Pozón Formations, eastern Falcon, Venezuela. Bull. Am. Paleontol., 39:67-251.

1969. Late middle Eocene to Recent planktonic foraminiferal biostratigraphy. In Brönniman, P., and Renz, H.H. (Eds.), Proc. First Int. Conf. Planktonic Microfossils, Geneva, 1967: Leiden (E.J. Brill), 1:199-422. , 1979. The Cainozoic Globigerinida: Leiden (E.J. Brill).

Blow, W.H., and Banner, F.T., 1962. The mid-Tertiary (upper Eocene to Aquitanian) Globigerinacea. In Eames, F.E., Banner, F.T., Blow, W.H., and Clarke, W.J. (Eds.), Fundamentals of Mid-Tertiary Stratigraphical Correlation: Cambridge (Cambridge Univ. Press), 61-151.

Blow, W.H., and Saito, T., 1968. The morphology and taxonomy of Globigerina mexicana Cushman, 1925. Micropaleontology, 14:357-360.

Boersma, A., and Premoli Silva, I., 1986. Terminal Eocene events: planktonic foraminiferal and isotopic evidence. In Pomerol, C., and Premoli Silva, I. (Eds.), Terminal Eocene Events: New York (Elsevier), 213-224.

Bolli, H.M., 1957a. Planktonic foraminifera from the Eocene Navet and San Fernando formations of Trinidad, B.W.I. Bull.-U.S. Nat. Mus., 215:155172

1957b. Planktonic foraminifera from the Oligocene-Miocene Cipero and Lengua formations of Trinidad, B.W.I. In Loeblich, A.R., Jr., Tappan, H., Beckmann, J.P., Bolli, H.M., Gallitelli, E.M., and Troelsen, J.C. (Eds.), Studies in Foraminifera. Bull.-U.S. Nat. Mus., 215:97-124. 1972. The genus Globigerinatheka Brönnimann. J. Foraminiferal Res., 2:109-136.

Bolli, H.M., Loeblich, A.R., Jr., and Tappan, H., 1957. Planktonic foraminiferal families Hantkeninidae, Orbulinidae, Globorotaliidae, and Globotruncanidae. Bull.-U.S. Nat. Mus., 215:3-50.

Borsetti, A.M., 1959. Tre nuovi Foraminiferi planctonici dell'Oligocene piacentino. G. Geol., 27:205-212.

Brönniman, P., 1952. Globigerinita and Globigerinatheka, new genera from the Tertiary of Trinidad, B.W.I. Cushman Found. Foraminiferal Res. Contrib., 3:25-28.

Chaproniere, G.C.H., 1981. Late Oligocene to early Miocene planktonic foraminifers from Ashmore Reef No. 1 well, northwest Australia. Alcheringa, 5:103-131.

1983. Tertiary larger foraminiferids from the northwestern margin of the Queensland Plateau, Australia. Bull-Bur. Miner. Resour., Geol. Geophys. (Aust.), 217:31-57.

Cifelli, R., 1972. The holotypes of Pulvinulina crassata var. densa Cushman and Globigerina spinuloinflata Bandy. J. Foraminiferal Res., 2:157-159.

Cole, W.S., 1927. A foraminiferal fauna from the Guayabal Formation in Mexico. Bull. Am. Paleontol., 14:1-46.

1928. A foraminiferal fauna from the Chapapote Formation in Mexico. Bull. Am. Paleontol., 14:1-32. 
Collot, J.-Y., Greene, H.G., Stokking, L.B., et al., 1992. Proc. ODP, Init. Repts., 134: College Station, TX (Ocean Drilling Program).

Cushman, J.A., 1925a. An Eocene fauna from the Moctezuma River, Mexico. AAPG Bull., 9:298-303. $66: 1-4$

1925b. A new genus of Eocene foraminifera. Proc. U.S. Nat. Mus.

1925c. New foraminifera from the upper Eocene of Mexico. Cushman Lab. Foraminiferal Res. Contrib., 1:4-8.

1927. An outline of a reclassification of the foraminifera. Cushman Lab. Foraminiferal Res. Contrib., 3:1-105.

- 1928. Additional foraminifera from the upper Eocene of Alabama. Cushman Lab. Foraminiferal Res. Contrib., 4:73-79.

Cushman, J.A., and Bermúdez, P.J., 1937. Further new species of foraminifera from the Eocene of Cuba. Cushman Lab. Foraminiferal Res. Contrib. 13:1-29.

Cushman, J.A., and Ponton, G.M., 1932. An Eocene foraminiferal fauna of Wilcox age from Alabama. Cushman Lab. Foraminiferal Res. Contrib., 8:51-72.

Davey, F.J., 1982. The structure of the South Fiji Basin. Tectonophysics, $87: 185-241$

Edwards, A.R., 1975. Southwest Pacific Cenozoic paleogeography and an integrated Neogene paleocirculation model. In Andrews, J.E., Packham, G., et al., Init. Repts. DSDP, 30: Washington (U.S. Govt. Printing Office), 667-684.

Finlay, H.J., 1939. New Zealand foraminifera; key species in stratigraphy, No. 2. Trans. R. Soc. N.Z., 69:89-128.

Gradstein, F.M., and Srivastava, P.P., 1980. Aspects of Cenozoic stratigraphy and paleoceanography of the Labrador Sea and Baffin Bay. Palaeogeogr. Palaeoclimatol., Palaeoecol., 30:261-295.

Gümbel, C.W., 1868. Beiträge zur Foraminiferenfauna der nordalpinen, älteren Eocängebilde oder der Kressenberger Nummulitenschichten. Bayerische Akad. Wiss. Abh., Math.-Physik. Kl., 10:579-730.

Hang, H., and Lindenberg, H.G., 1966. Revizija Globigerina (Subbotina) eocaena Gümbel iz Eocena predgorij Bavarskich Al'p. Akad. Nauk SSSR Voprosy Mikropaleontol., 10:342-358.

Haq, B.U., Premoli Silva, I., and Lohmann, G.P., 1977. Calcareous plankton paleobiogeographic evidence for major climatic fluctuations in the early Cenozoic Atlantic Ocean. J. Geophys. Res., 82:3861-3876.

Hornibrook, N. de B, 1958. New Zealand Upper Cretaceous and Tertiary foraminiferal zones and some overseas correlations. Micropaleontology, $4: 25-38$.

- 1961. Tertiary foraminifera from Oamaru District (N.Z.). Part 1Systematics and distribution. N.Z. Geol. Surv. Paleontol. Bull., 34:1-192.

, 1965. Globigerina angiporoides $\mathrm{n}$. sp. from the upper Eocene and lower Eocene of New Zealand and the status of Globigerina angipora Stache, 1865. N.Z. J. Geol. Geophys., 8:834-838.

Howe, H.V., and Wallace, W.E., 1932. Foraminifera of the Jackson Eocene at Danville Landing on the Ouachita, Catahoula Parish, Louisiana. Louisiana Dept. Conserv. Geol. Bull., 2:18-79.

Jenkins, D.G., 1960. Planktonic foraminifera from the Lakes Entrance oil shaft, Victoria, Australia. Micropaleontology, 6:345-371.

, 1966. Planktonic foraminiferal zones and new taxa from the Danian to lower Miocene of New Zealand. N.Z. J. Geol. Geophys., 8:1088-1126.

, 1971. New Zealand Cenozoic planktonic foraminifera. N.Z. Geol. Surv. Paleontol. Bull., 42:1-278.

, 1975. Cenozoic planktonic foraminiferal biostratigraphy of the Southwestern Pacific and Tasman Sea-DSDP Leg 29. In Kennett, J.P., Houtz, R.E., et al., Init. Repts. DSDP, 29: Washington (U.S. Govt. Printing Office), 449-467.

Jenkins, D.G., and Orr, W.N., 1973. Globigerina utilisindex n. sp. from the upper Eocene-Oligocene of the eastern equatorial Pacific. J. Foraminiferal Res., 3:133-135.

Jenkins, D.G., and Srinivasan, M.S., 1986. Cenozoic planktonic foraminifers from the equator to the sub-antarctic of the Southwest Pacific. In Kennett, J.P., von der Borch, C.C., et al., Init. Repts. DSDP, 90 (Pt. 2): Washington (U.S. Govt. Printing Office), 795-834.

Keller, G., 1983. Biochronology and paleoclimatic implications of middle Eocene to Oligocene planktonic foraminiferal faunas. Mar. Micropaleontol., 7:463-486.

Kennett, J.P., 1977. Cenozoic evolution of Antarctic glaciation, the circumAntarctic Ocean, and their impact on global paleoceanography. J. Geophys. Res., 82:3843-3860.
Kennett, J.P., and von der Borch, C.C., 1986. Southwest Pacific Cenozoic paleoceanography. In Kennett, J.P., von der Borch, C.C., et al., Init. Repts. DSDP. 90 (Pt. 2): Washington (U.S. Govt. Printing Office), 1493-1517.

Koch, R., 1926. Mitteltertiäre Foraminiferen aus Bulongan, Ost Borneo. Ecologae Geol. Helv., 19:722-751.

Kroenke, L.W., 1984. Cenozoic tectonic development of the southwest Pacific. Tech. Bull.-U.N. Econ. Soc. Comm. Asia Pac., Comm. Co-ord. Jt. Prospect Miner. Resour. South Pac. Offshore Areas, 6.

Murphy, M.G., and Kennett, J.P., 1986. Development of latitudinal thermal gradients during the Oligocene: oxygen-isotope evidence from the southwest Pacific. In Kennett, J.P., von der Borch, C.C., et al., Init. Repts. DSDP, 90: Washington (U.S. Govt. Printing Office), 1347-1360.

Myatliuk, E.V., 1950. Stratigrafiya flishevykh osadkov severnykh Karapat v cveta dannykh fauny foraminifer. Veses. Neft. Nauchno-Issled. Geol.-Razved. Inst. Trudy, 51:225-287.

Nocchi, M., Parisi, G., Monaco, P., Monechi, D., and Madile, M., 1988. Eocene and early Oligocene micropaleontology and paleoenvironments in SE Umbria, Italy. Palaeogeogr., Palaeoclimatol., Palaeoecol., 67:181-244.

Nocchi, M., Parisi, G., Monaco, P., Monechi, S., Madile, M., Napoleone, G., Ripepe, M., Orlando, M., Premoli Silva, I., and Bice, D.M., 1986. The Eocene-Oligocene boundary in the Umbrian pelagic sequences. In Pomerol, C., and Premoli Silva, I. (Eds.), Terminal Eocene Events: New York (Elsevier), Dev. Paleontol. Stratigr., 9:25-40.

Okada, H., and Bukry, D., 1980. Supplementary modification and introduction of code numbers to the low-latitude coccolith biostratigraphic zonation (Bukry, 1973; 1975). Mar. Micropaleontol., 5:321-325.

Packham, G.H., and Andrews, J.E., 1975. Results of Leg 30 and the geologic history of the Southwest Pacific arc and marginal sea complex. In Andrews, J.E., Packham, G., et al., Init. Repts. DSDP, 30: Washington (U.S. Govt. Printing Office), 691-705.

Palmer, D.K., 1934. The foraminiferal genus Gümbelina in the Tertiary of Cuba. Mem. Soc. Cubana Hist. Nat., 8:73-76.

Parson, L., Hawkins, J., Allan, J., et al., 1992. Proc. ODP, Init. Repts., 135: College Station, TX (Ocean Drilling Program).

Pijpers, P.J., 1933. Geology and paleontology of Bonaire (D.W.I.). Univ. Utrecht Geol. Med., Phys.-Geol. Reeks, 8:1-103.

Premoli Silva, I., and Boersma, A., 1988. Atlantic Eocene planktonic foraminiferal historical biogeography and paleohydrographic indices. Palaeogeogr., Palaeoclimatol., Palaeoecol., 67:315-356.

1989. Atlantic Paleogene planktonic foraminiferal bioprovincial indices. Mar. Micropaleontol., 14:357-371.

Spezzaferri, S., and Premoli Silva, I., 1991. Oligocene planktonic foraminiferal biostratigraphy and paleoclimatic interpretation from Hole 538A, DSDP Leg 77, Gulf of Mexico. Palaeogeogr., Palaeoclimatol., Palaeoecol. $83: 217-263$.

Stainforth, R.M., and Lamb, J.L., 1981. An evaluation of planktonic foraminiferal zonation of the Oligocene. Univ. Kansas Paleontol. Contrib., 104:1-42.

Subbotina, N.N., 1953. Iskopaemye foraminifery SSSR; Globigerinidae, Hantkeninidae, $i$ Globorotaliidae. Veses. Neft. Nauchno-Issled. Geol.Razved. Inst. Trudy, 76.

, 1971. Fossil Foraminifera of the USSR: Globigerinidae, Hantkeninidae and Globorotaliidae: London (Collet's Ltd.).

Todd, R., 1957. Smaller Foraminifera. In Geology of Saipan, Mariana Islands (Pt. 3): Paleontology. Geol. Surv. Prof. Pap. U.S., 280-H:265-320.

Toumarkine, M., and Bolli, H.M., 1970. Evolution de Globorotalia cerroazulensis (Cole) dans l'Eocène moyen et supérieur de Possagno (Italie). Rev. Micropaleontol., 13:131-145.

Toumarkine, M., and Luterbacher, H., 1985. Paleocene and Eocene planktic foraminifera. In Bolli, H.M., Saunders, J.B., and Perch-Nielsen, K. (Eds.), Plankton Stratigraphy: Cambridge (Cambridge Univ. Press), 87-154.

Weinzierl, L.L., and Applin, E.R., 1929. The Claibourne Formation on the coastal domes. J. Paleontol., 3:384-410.

Weissel, J.K., Watts, A.B., and Lapouille, A., 1982. Evidence for late Paleocene to late Eocene seafloor in the southern New Hebrides Basin. Tectonophysics, 87:243-251.

Date of initial receipt: 27 August 1992

Date of acceptance: 2 February 1993

Ms 135SR-114 


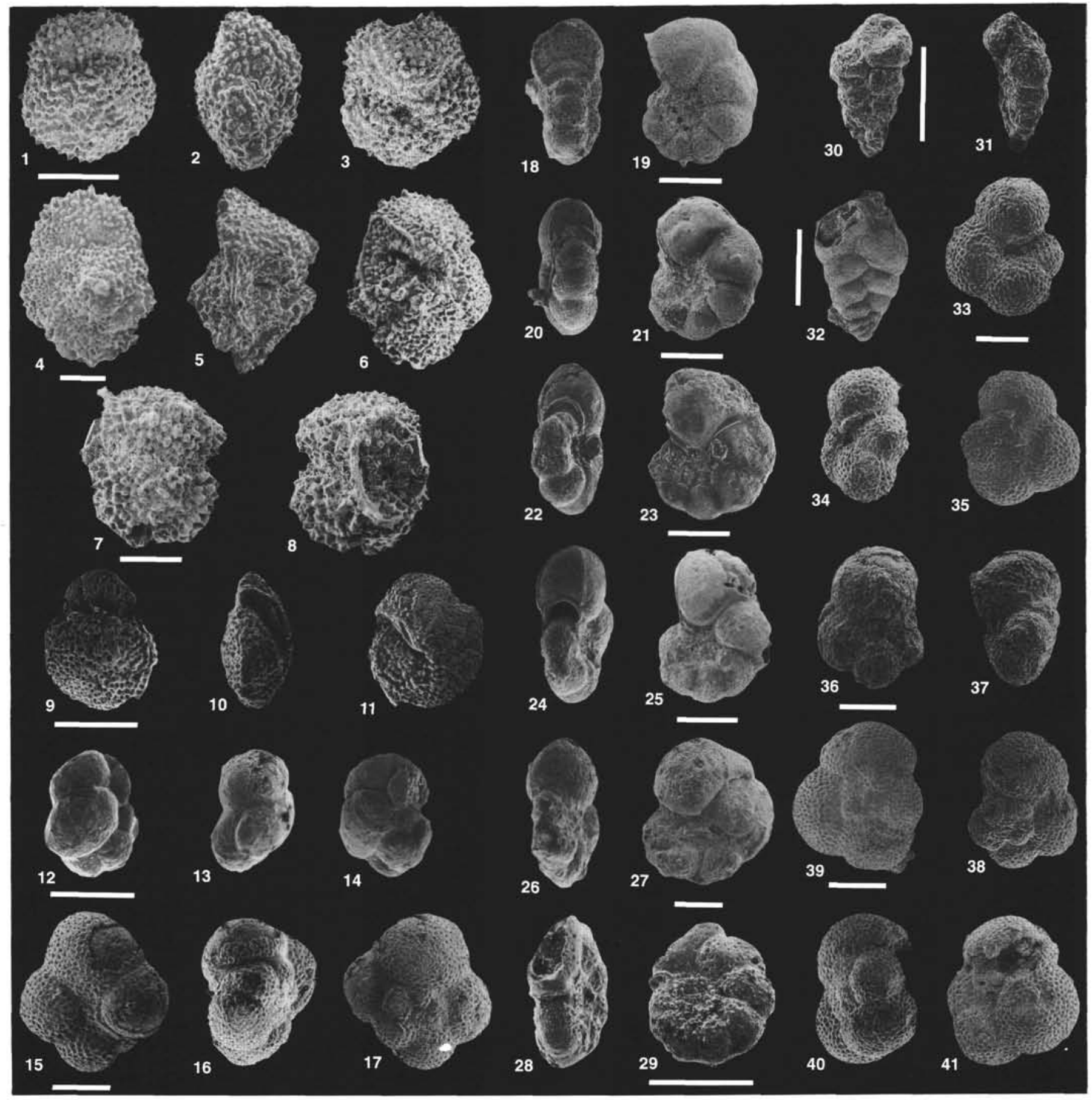

Plate 1. Scale bar $=100 \mu \mathrm{m} . \quad$ 1-3. Acarinina densa, Sample 135-841B-47R-1, 66-70 cm (1, spiral view; 2, side view; 3, umbilical view). 4-6. Morozovella spinulosa, Sample 135-841B-47R-1, 66-70 cm (4, spiral view; 5, side view; 6, umbilical view). 7, 8. Truncorotaloides topilensis, Sample 135-841B-47R-1, 66-70 cm (7, spiral view; 8, umbilical view). 9-11. Planorotalites renzi, Sample 135-841B-47R-1, 66-70 cm (9, spiral view; 10, side view; 11, umbilical view). 12-14. Cassigerinella chipolensis, Sample 135-841B-42R-1, $92-96 \mathrm{~cm}$ (12, side view; 13, peripheral view; 14, side view). 15-17. Globorotaloides suteri, Sample 135-84IB-42R-3, 80-83 cm (15, spiral view; 16, side view; 17, umbilical view). 18, 19. Pseudohastigerina wilcoxensis, Sample 135-841B-44R-2, 28-31 $\mathrm{cm}$ (18, apertural face; 19, lateral view). 20, 21. Pseudohastigerina wilcoxensis, Sample 135-841B-44R-2, 28-31 cm (20, apertural face; 21, lateral view). 22, 23. Pseudohastigerina danvillensis, Sample $135-841 \mathrm{~B}-44 \mathrm{R}-2,28-31 \mathrm{~cm}$ (22, apertural face; 23, lateral view). 24, 25. Pseudohastigerina micra, Sample 135-841B-45R-1, 60-65 cm (24, apertural face; 25, lateral view). 26, 27. Pseudohastigerina micra, Sample 135-841B-45R-1, 25-28 cm (26, apertural face; 27, lateral view). 28, 29. Pseudohastigerina barbadoensis, Sample 135-841B-45R-1, $60-65 \mathrm{~cm}$ (28, apertural face; 29 , lateral view). 30, 31. Chiloguembelina cubensis, Sample 135-841B-45R-1, 25-28 cm (30, lateral view; 31, edge view). 32. Chiloguembelina martini, Sample 135-841B-44R-2, 28-31 cm, lateral view. 33-35. Tenuitella munda, Sample 135-841B-42R-1, 92-96 cm (33, umbilical view; 34, side view; 35, spiral view). 36-38. Globigerinella obesa, Sample 135-841B-42R-3, 80-83 cm (36, umbilical view; 37, side view; 38, spiral view). 39-41. Paragloborotalia opima nana, Sample 135-841B-42R-1, 92-96 cm (39, umbilical view; 40 , side view; 41 , spiral view). 


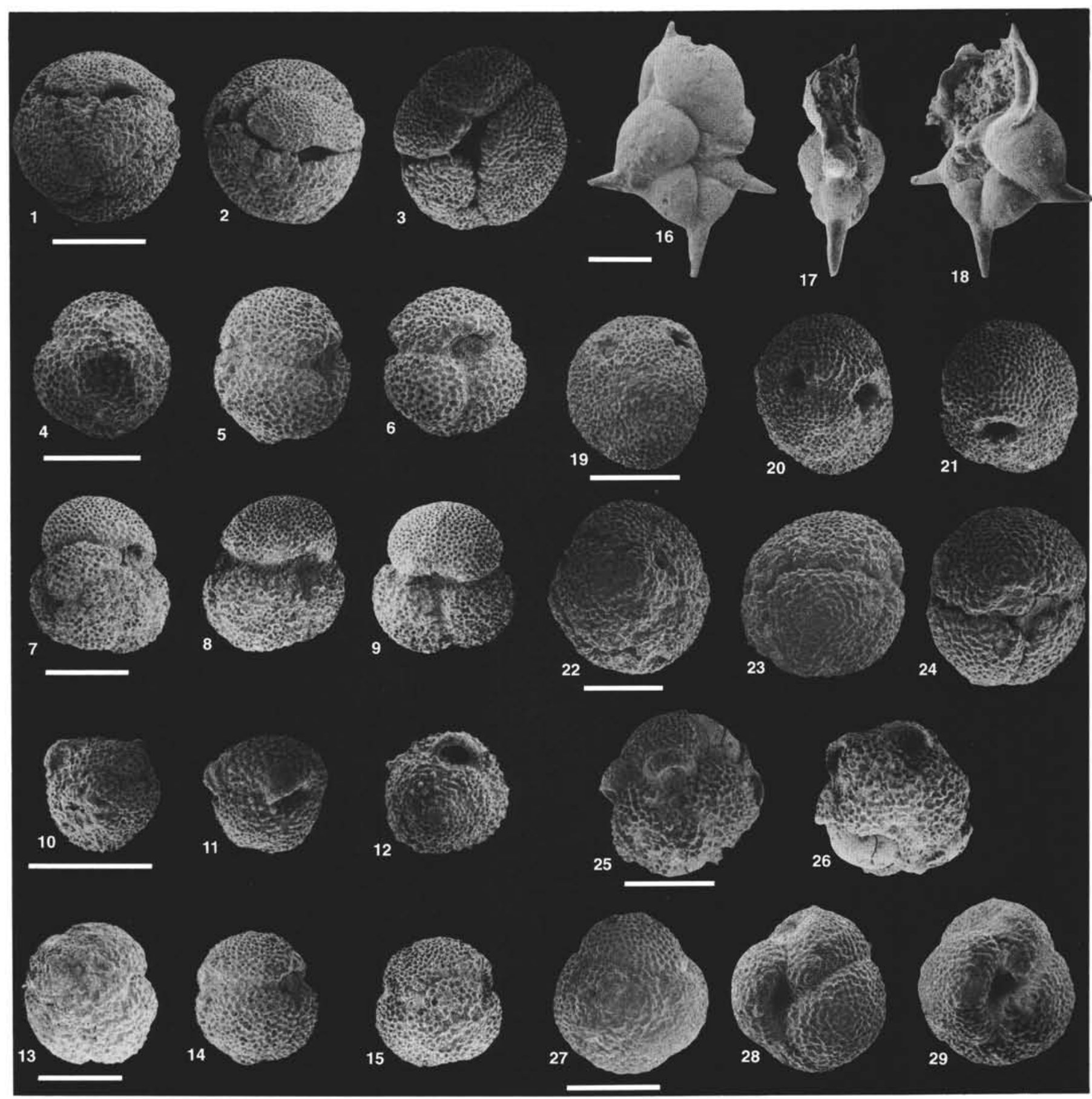

Plate 2. Scale bar $=200 \mu \mathrm{m}$. 1-3. Globigerinatheka subconglobata luterbacheri, Sample 135-841B-44R-1, 17-20 cm (1, spiral view; 2, side view; 3, umbilical view). 4-6. Globigerinatheka index tropicalis, Sample 135-84IB-45R-1, 60-65 cm (4, spiral view; 5, sidè view; 6, umbilical view). 7-9. Globigerinatheka index tropicalis, Sample 135-841B-44R-2, 28-31 cm (7, spiral view; 8, side view; 9, umbilical view). 10-12. Globigerinatheka mexicana barri, Sample 135-841B-44R-2, 28-31 cm (10, spiral view; 11-12, side view). 13-15. Globigerinatheka mexicana mexicana, Sample 135-841B-45R-1, 60-65 cm (13, side view; 14, 15, spiral view). 16-18. Hantkenina alabamensis, Sample 135-841B-45R-1, 60-65 cm (16, lateral view; 17, apertural face; 18, lateral view). 19-21. Globigerinatheka cf. semiinvoluta, Sample 135-841B-45R-1, 60-65 cm (19, spiral view; 20, side view; 21, umbilical view). 22-24. Globigerinatheka index index, Sample 135-841B-44R-2, 28-31 cm (22, spiral view; 23, side view; 24, umbilical view). 25, 26. Globigerinatheka mexicana barri, Sample 135-841B45R-1, 60-65 cm, side view. 27-29. Catapsydrax globiformis, Sample 135-841B-44R-2, 28-31 cm (27, spiral view; 28, side view; 29, umbilical view). 


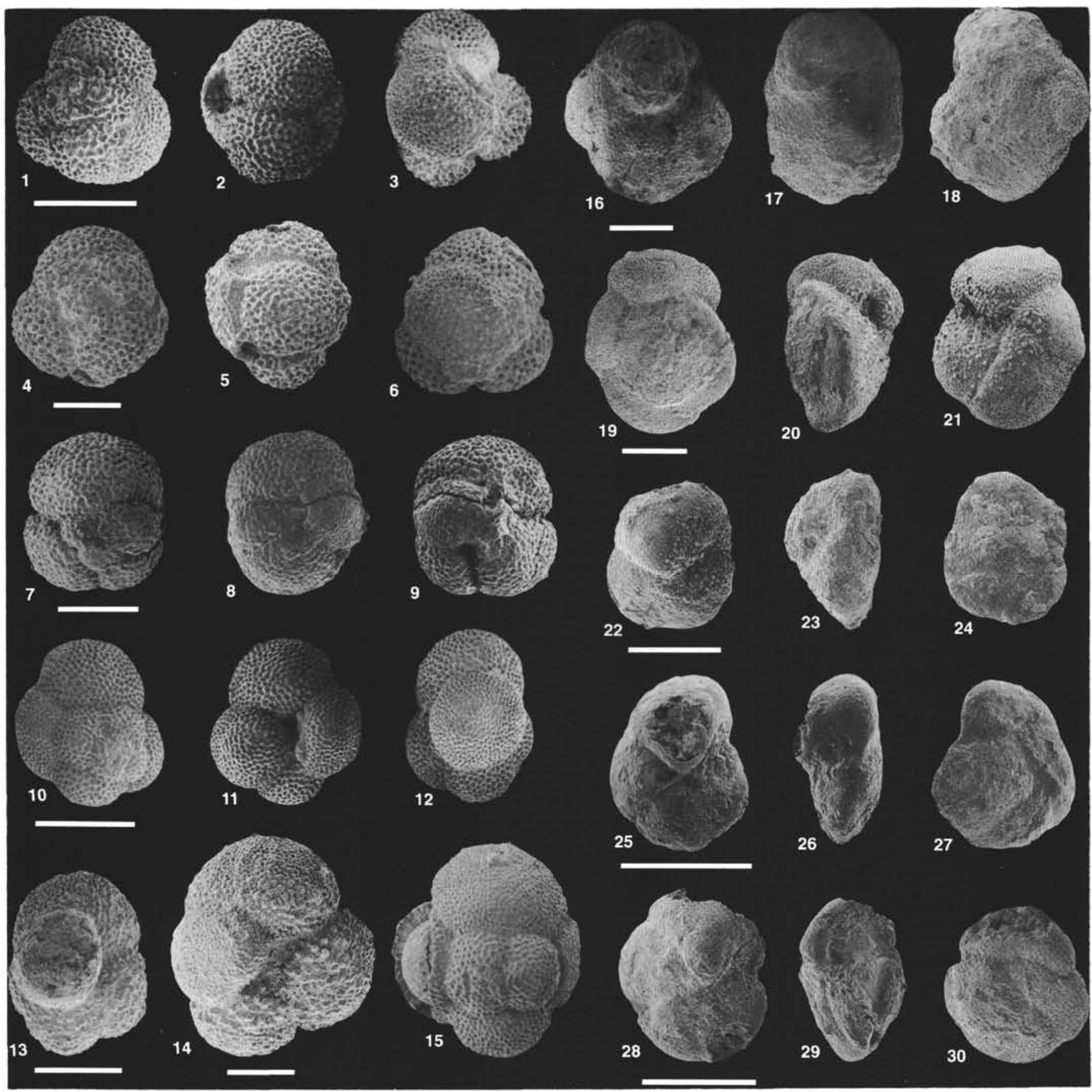

Plate 3. Scale bar $=200 \mu \mathrm{m}$. 1-3. Catapsydrax howei, Sample 135-841B-44R-2, 28-31 cm (1, spiral view; 2, side view; 3, umbilical view). 4-6. Catapsydrax africanus, Sample 135-841B-45R-1, 60-65 cm (4, spiral view; 5, side view; 6, umbilical view). 7-9. Catapsydrax africanus, Sample 135-841B-44R-1, 17-21 $\mathrm{cm}$ (7, spiral view; 8, side view; 9, umbilical view). 10-12. Catapsydrax pera, Sample 135-841B-44R-1, 17-20 cm (10, spiral view; 11, side view; 12, umbilical view). 13. Catapsydrax martini, Sample 135-841B-42R-4, 89-93 cm, umbilical view. 14-15. Catapsydrax unicavus, Sample-135-841B-44R-2, 28-31 cm (14, umbilical view; 15, spiral view). 16-18. Turborotalia centralis, Sample 135-841B-45R-1, 25-28 cm (16, umbilical view; 17, side view; 18, spiral view). 19-21. Turborotalia cerroazulensis cerroazulensis, Sample 135-841B-44R-2, 28-31 cm (19, spiral view; 20, side view; 21, umbilical view). 22-24. Turborotalia cerroazulensis cerroazulensis, Section 135-841B-45R-CC (22, umbilical view; 23, side view; 24, spiral view). 25-27. Turborotalia cerroazulensis cocoaensis, Section 135-841B-45R-CC (25, umbilical view; 26, side view; 27, spiral view). 28-30. Turborotalia cerroazulensis cocoaensis, Section 135-841B-45R-CC (28, umbilical view; 29 , side view; 30 , spiral view). 


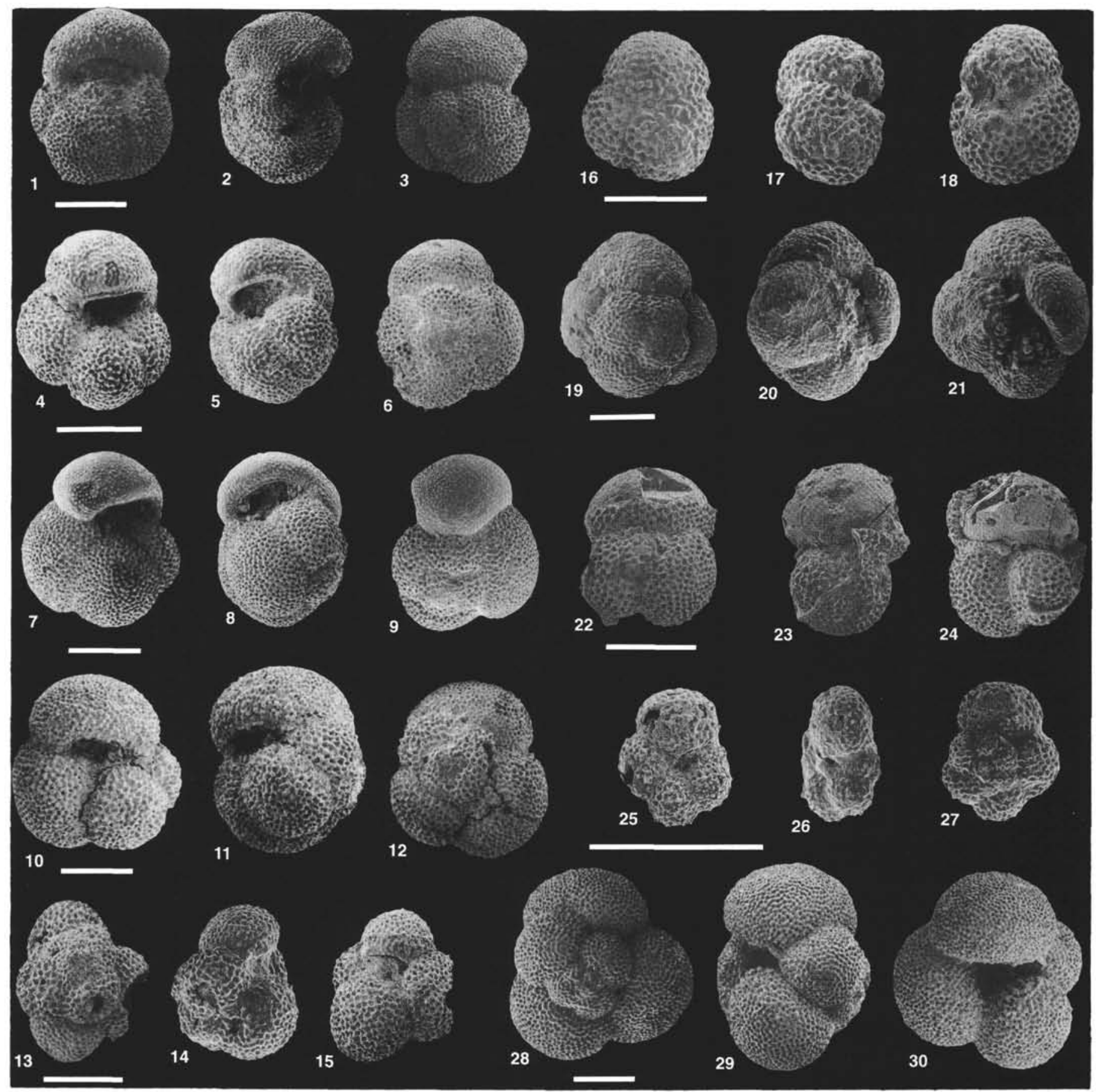

Plate 4. Scale bar $=200 \mu \mathrm{m}$. 1-3. "Globigerina" ampliapertura, Section 135-841B-41R-CC (1, umbilical view; 2, side view; 3, spiral view). 4-6. "Globigerina" ampliapertura, Section 135-841B-41R-CC (4, umbilical view; 5, side view; 6, spiral view). 7-9. Turborotalia increbescens, Section 135-841B4IR-CC (7, umbilical view; 8, side view; 9, spiral view). 10-12. "Globigerina" euapertura, Section 135-841B-41R-CC (10, umbilical view; 11, side view; 12, spiral view). 13-15. Globigerina senilis, Sample 135-841B-45R-1, 60-65 cm (13, spiral view; 14, side view; 15, umbilical view). 16-18. Subbotina brevis, Section 135-841B-41R-CC (16, spiral view; 17, side view; 18, umbilical view). 19-21. Subbotina corpulenta, Sample 135-841B-44R-2, 28-31 cm (19, spiral view; 20, side view; 21, umbilical view). 22-24. Subbotina linaperta, Sample 135-841B-44R-2, 28-31 cm (22, spiral view; 23, side view; 24, umbilical view). 25-27. Globigerina angustiumbilicata, Sample 135-841B-45R-1, 60-65 cm (25, umbilical view; 26 , side view; 27, spiral view). 28-30. Subbotina gortanii, Section 135-841B-41R-CC (28, umbilical view; 29, side view; 30, spiral view). 


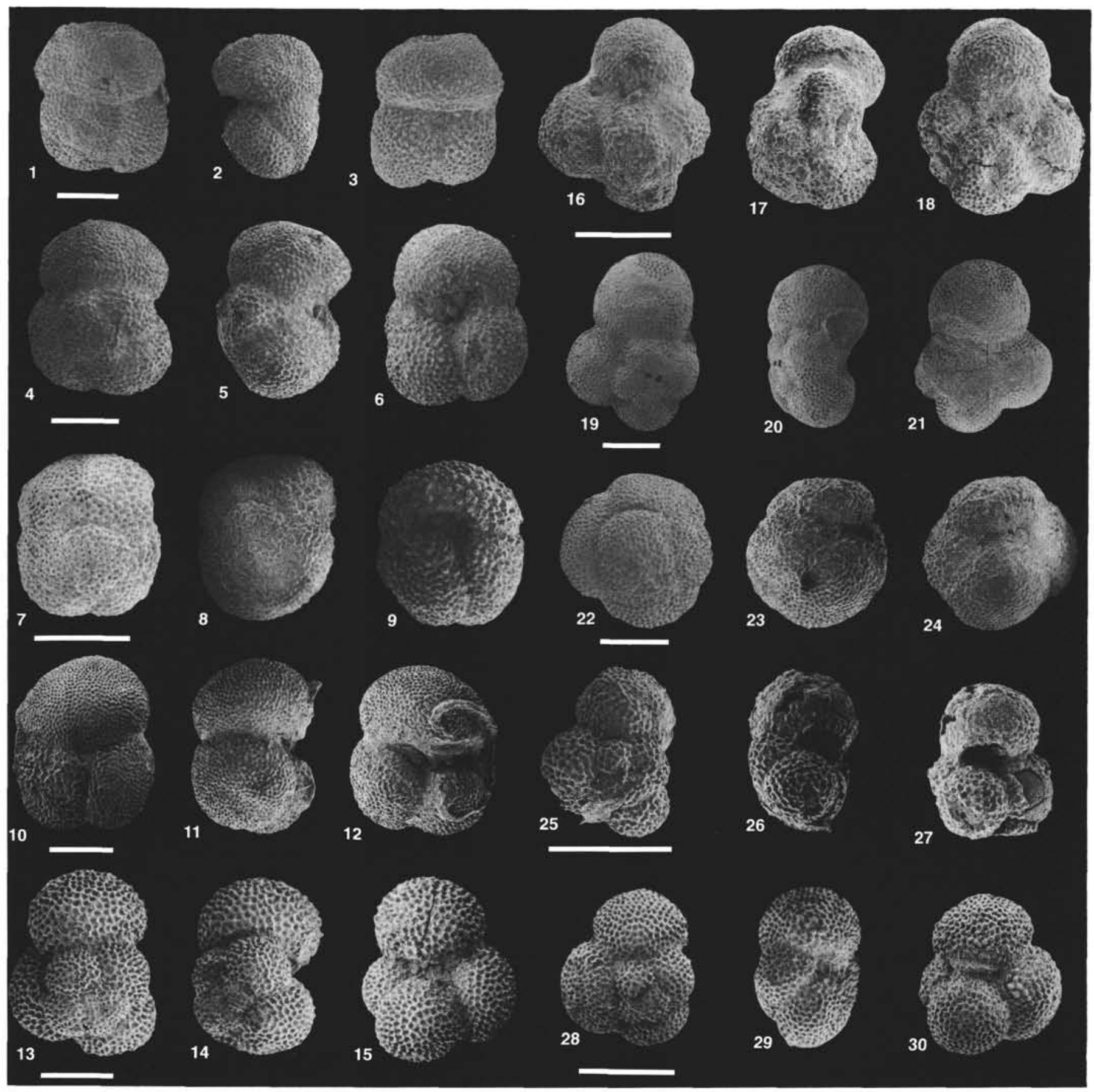

Plate 5. Scale bar $=200 \mu \mathrm{m}$. 1-3. Dentoglobigerina tripartita, Sample 135-841B-43R-1, 21-25 cm (1, spiral view; 2, side view; 3, umbilical view). 4-6. Dentoglobigerina tapuriensis, Sample 135-841B-42R-1, 92-96 cm (4, spiral view; 5, side view; 6, umbilical view). 7-9. Dentoglobigerina sellii, Sample 135-841B-43R-1, 21-25 cm (7, spiral view; 8, side view; 9, umbilical view). 10-12. Dentoglobigerina galavisi, Sample 135-841B-44R-2, 28-31 cm (10, spiral view; 11, side view; 12, umbilical view). 13-15. Subbotina yeguaensis, Sample 135-841B-44R-2, 28-31 cm (13, umbilical view; 14, side view; 15, spiral view). 16-18. Globigerina officinalis, Sample 135-841B-45R-1, 25-28 cm (16, spiral view; 17, side view; 18, umbilical view). 19-21. Subbotina eocaena, Sample 135-841B-44R-CC (19, spiral view; 20, side view; 21, umbilical view). 22-24. "Globigerina" pseudovenezuelana, Sample 135-841B-44R-2, 28-31 cm (22, spiral view; 23, side view; 24, umbilical view). 25-27. Globigerina praebulloides, Sample 135-841B-45R-1, 60-65 cm (25, spiral view; 26, side view; 27, umbilical view). 28-30. Subbotina angiporoides, Sample 135-841B-44R-2, 28-31 cm (28, umbilical view; 29, side view; 30, spiral view). 